\title{
Historical Rainfall and Evapotranspiration Changes over Mpologoma Catchment in Uganda
}

\author{
Ambrose Mubialiwo $\mathbb{D D}^{1,2}$ Charles Onyutha ${ }^{10}{ }^{2}$ and Adane Abebe ${ }^{1,3}$ \\ ${ }^{1}$ Africa Center of Excellence for Water Management, Addis Ababa University, P.O. Box 1176, Addis Ababa, Ethiopia \\ ${ }^{2}$ Department of Civil and Building Engineering, Kyambogo University, P.O. Box 1, Kyambogo, Kampala, Uganda \\ ${ }^{3}$ Department of Water Resources and Irrigation Engineering, Arba Minch University, P.O. Box 21, Arba Minch, Ethiopia
}

Correspondence should be addressed to Ambrose Mubialiwo; mambroze@gmail.com

Received 26 March 2020; Accepted 15 May 2020; Published 28 May 2020

Academic Editor: Roberto Coscarelli

Copyright (C) 2020 Ambrose Mubialiwo et al. This is an open access article distributed under the Creative Commons Attribution License, which permits unrestricted use, distribution, and reproduction in any medium, provided the original work is properly cited.

\begin{abstract}
Changes in the long-term (1948-2016) rainfall and evapotranspiration over Mpologoma catchment were analysed using gridded $\left(0.25^{\circ} \times 0.25^{\circ}\right)$ Princeton Global Forcing data. Trend and variability were assessed using a nonparametric approach based on the cumulative sum of the difference between exceedance and nonexceedance counts of data. Annual and March-May (MAM) rainfall displayed a positive trend $(p<0.05)$, whereas October-December (OND) and June-September rainfall exhibited negative trends with $p>0.05$ and $p<0.05$, respectively. Positive subtrends in rainfall occurred in the 1950s and from the mid-2000s till 2016; however, negative subtrends existed between 1960 till around 2005. Seasonal evapotranspiration exhibited a positive trend $(p>0.05)$. For the entire period (1948-2016), there was no negative subtrend in the OND and MAM evapotranspiration. Rainfall and evapotranspiration trends and oscillatory variation in subtrends over multidecadal time scales indicate the need for careful planning of predictive adaptation to the impacts of climate variability on environmental applications which depend on water balance in the Mpologoma catchment. It is recommended that future studies quantify possible contributions of human factors on the variability of rainfall and evapotranspiration. Furthermore, climate change impacts on rainfall and evapotranspiration across the study area should be investigated.
\end{abstract}

\section{Introduction}

Analyses of the spatial and temporal changes in rainfall and evapotranspiration provide an insight into the influences of anthropogenic factors on the catchment hydrological processes [1-3]. In Uganda, approximately $70 \%$ of the population depends on agriculture [4], which contributes about $25 \%$ of the country's Gross Domestic Product (GDP) [5]. Rainfall plays a key role in the livelihood of agricultural households in low-income countries, Uganda being inclusive, as most farmers primarily depend on rain-fed agriculture [6], hence vulnerable to extreme weather events like drought, floods, etc. Similarly, evapotranspiration is an important element of the soil water balance serving a significant part in determining the potential harvest in the agricultural sector. Therefore, the variations in rainfall and evapotranspiration result in disasters such as drought and floods which impact on a number of sectors $[7,8]$.

Mpologoma catchment within the White Nile basin is in the highlands of Mount Elgon within Manafwa and Bududa districts which are prone to rainfall-induced landslides. Within the same study area, the low-lying areas of Tororo and Butaleja district are vulnerable to flooding $[9,10]$. The recent events that claimed lives and destroyed properties include (1) the floods of December 2019 with at least 4 deaths and over 2,000 people displaced [11] and (2) the October 2018 severe floods and landslides in Bududa, displacing 858 people, with 51 deaths and a total of 12,000 people being affected [12]. Similarly, the severe landslides of March 2010 killed over 400 people, displacing 5,000 people in Bududa district [13], and over 33,000 households were affected in 
Butaleja [14]. These events tend to occur annually. The weather conditions related to the surplus of water tend to be punctuated by long dry spells; for instance, after the floods and landslide in 2014, there was a long dry spell [15]. The changes in catchment characteristics by prolonged dry conditions and flooding events could implicate the possible impacts of human factors on the hydrology. The area around Mt. Elgon is known for the encroachment of gazetted forest reserve by the local population for human settlement and farming. The massive deforestation exposes the soil so that it can be easily saturated and carried away. Alongside the human factors, there could also be the influence of climate variability on the hydrometeorology of the study area. A careful analysis of the variation in rainfall and potential evapotranspiration as indicators of water balance is vital for predictive planning of water resources management applications.

Several studies have been conducted to evaluate the variability of climatic variables particularly rainfall and temperature. These were conducted at regional scales, e.g., Kansiime et al. [16]; at large water basins, e.g., Kizza et al. [17], Nyeko-Ogiramoi et al. [18], Onyutha and Willems [19], Alemu et al. [20], Onyutha [21], and Mugume et al. [22]; and countrywide scales, e.g., Phillips and Mcintyre [23], Nsubuga et al. [24], Mwaura and Okoboi [25], Majaliwa et al. [26], Onyutha [27], and Jury [28]. In other words, studies conducted on the analysis of trends and variability of rainfall and evapotranspiration across the Mpologoma catchment are lacking. This could be due to the lack of observed longterm data. Furthermore, most studies focused on rainfall and temperature variability except Alemu et al. [20] and Onyutha [21] that considered evapotranspiration. Whereas the analysis of temperature can give an insight into the evapotranspiration, the end-user especially the farmers require exact information on the evapotranspiration. Furthermore, there is a challenge of poor distribution of meteorological stations to generate reliable large-scale observed data [29], short-term-record length, with few data being available in recent years, of which its quality is also uncertain and questionable [30], which affects the trend and variability analyses.

Spatial and temporal changes can be examined in terms of trend and variability. Some of the variability analysis methods include Autocorrelation Spectral Analysis (ASA) [31], the Quantile Perturbation Method (QPM) [32], and the Empirical Orthogonal Functions (EOF) [33]. Similarly, trend analyses can be performed using parametric or nonparametric methods. Some of the parametric methods include the least-squares linear regression [34] and Sen's robust slope estimator [35]. The common nonparametric methods include Mann-Kendall (MK) [36, 37], Spearman's rank correlation [38, 39], and Cumulative Sum of the Difference (CSD) between exceedance and nonexceedance counts of data points $[21,27,40]$. Some of the recent studies that applied the CSD method include those by Onyutha et al. [41], Cengiz et al. [42], Vido et al. [43], Tang and Zhang [44], and Pirnia et al. [45]. Because of its ability to analyse both trends and variability [46], the CSD method was adopted in this study. Thus, this study aimed at analysing the rainfall and evapotranspiration trends and variability across Mpologoma catchment in Uganda.

\section{Materials and Methods}

2.1. Study Area. Mpologoma catchment is approximately $9,000 \mathrm{~km}^{2}$ (see Figure 1). The catchment is one of the Kyoga Water Management Zone (KWMZ) [10] catchments, stretching between latitudes $0^{\circ} 19^{\prime} \mathrm{N}$ and $1^{\circ} 20^{\prime} \mathrm{N}$ and longitudes $33^{\circ} 20^{\prime} \mathrm{E}$ and $34^{\circ} 40^{\prime} \mathrm{E}$. Part of Mpologoma catchment is the River Malaba Basin having an area of approximately $3,500 \mathrm{~km}^{2}$.

The rainfall over the study area occurs in two seasons with the first and more intense from March to May (MAM) while the second and highly variable occurs between October and December (OND). The area receives an average annual rainfall of approximately $1,375 \mathrm{~mm}$, but the districts of Mbale, Bududa, and Manafwa receive slightly higher rains, on average $1,800 \mathrm{~mm}$ per annum. The catchment climate may be influenced by the presence of great lakes (such as Lake Victoria and Lake Kyoga) and the mountain Elgon slope breezes that tend to affect the afternoon convection [47]. This results in high variability of weather elements particularly rainfall [10]. Largely, the area experiences evapotranspiration particularly from the swamp vegetation [48].

In Figure 1, the background map is the annual rainfall total $(\mathrm{mm})$ obtained by the ordinary kriging interpolation method [49] based on data from 1948 to 2016. The choice of ordinary kriging was based on its ability to minimise the variance of the errors as it estimates the weighted linear combination of the available data and is unbiased as it strives to have a mean residual or error of zero [50]. It is noticeable that annual rainfall ranges from about 1000 to $1350 \mathrm{~mm}$. The highest rainfall $(1350 \mathrm{~mm})$ occurs near the shores of Lake Kyoga.

\subsection{Data}

2.2.1. Rainfall and Potential Evapotranspiration Data. Some of the freely available reanalysis temperature and precipitation products include the Climate Research Unit (CRU) [51], Precipitation Estimation from Remotely Sensed Information using Artificial Neural Networks Climate Data Record (PERSIANN-CDR) [52], Tropical Rainfall Measuring Mission (TRMM) Multisatellite Precipitation Analysis (TMPA) [53], African Rainfall Climatology (ARC) [54], and Princeton Global Forcing (PGF) [55]. A number of these products have short-term records, despite having data up to recent years. For instance, the PERSIANN-CDR, TRMMTMPA, and ARC data series cover periods from 1983 [52], 1998 [53], and 1983 [54], respectively. However, some data such as the PGF cover a long-term period (1948 to 2016) in addition to the high spatial resolution of $0.25^{\circ} \times 0.25^{\circ}$ [55]. Recently, the CRU TS v4 monthly PET data calculated based on the standard Penman-Monteith method was released for use [56]. The CRU TS v4 data are managed by the United Kingdom's Natural Environment Research Council (NERC). The earlier version of this PET data (CRU TS3.10) [51] was 


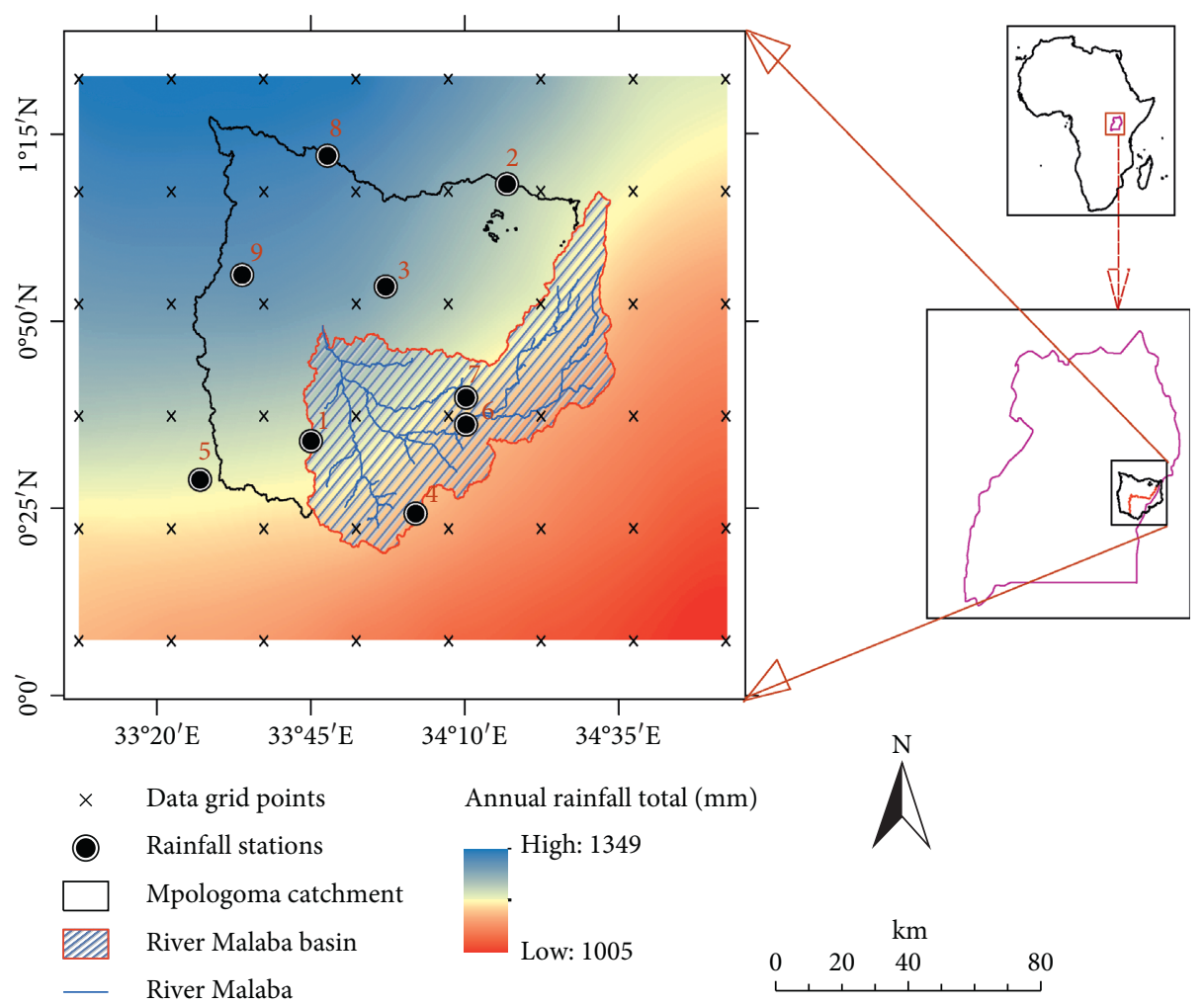

FIGURE 1: Location of the study area showing the data grid points and locations of the selected rainfall stations detailed in Table 1. Surface interpolation by the ordinary kriging technique was used to obtain the background map from the annual rainfall total (mm) of 1948-2016.

used by one of the authors of this paper [21]. However, the CRU TS3.10 PET was in the form of the countrywide average series. Furthermore, the CRU TS v4 PET data are of the spatial resolution of $0.5^{\circ} \times 0.5^{\circ}$ [56] which was still deemed coarse with respect to the size of the catchment considered as the study area. For reasonable results of analyses in rainfall and PET changes across a small catchment like Mpologoma, high-resolution spatial and long-term data is required. Eventually, the PGF was chosen because the temperature and precipitation series with a spatial resolution of $0.25^{\circ} \times 0.25^{\circ}$ was available and ultimately used in this study. PGF dataset is commonly used because of its high spatial and temporal resolutions, global coverage, long-term record period, and robustness particularly for trend and variability analyses, as previously demonstrated in several studies $[27,30,57-60]$.

Daily global precipitation and the minimum $\left(T_{\min }\right)$ and maximum $\left(T_{\max }\right)$ temperature data of the PGF [55] were acquired online in a gridded form of $0.25^{\circ} \times 0.25^{\circ}$ from http://hydrology.princeton.edu/data/pgf/0.5deg/(accessed: 10 January 2020). The data covers a period from 1948 to 2016. The PGF data possessed no missing values over the considered period (1948 to 2016) at all the selected 48 grid points (Figure 1). PGF observational-based dataset was developed using a blend of National Centers for Environmental Prediction-National Center for Atmospheric Research (NCEP-NCAR) reanalysis dataset [61] and other several global, observational datasets including the Climate Research Unit (CRU) TS2.0, Tropical Rainfall Measuring
Mission (TRMM), Global Precipitation Climatology Project (GPCP), and National Aeronautics and Space Administration (NASA) Langley Surface Radiation Budget [55].

Despite the wide adoption of reanalysis datasets, they are known to be predisposed in replicating the observed extreme events [62-64]. Hence, it was deemed vital to assess the validity of the PGF rainfall products. To do so, rainfall data at nine rain gauging stations (see Table 1) were obtained from the Uganda National Meteorological Authority under the Ministry of Water and Environment.

It is noticeable from Table 1 that the period of available data varies from one station to another with most stations having data ending in the 1980s. This is due to the nonfunctionality of the situation caused by the civil war that started in 1981, where many rainfall stations across Uganda were broken down and observations stopped according to the report by the Japan International Cooperation Agency (JICA) [65]. Due to the lack of observed evaporation data in the study area, PGF data was assessed using only the observed rainfall from the selected stations.

As a quality control procedure, the infilling of missing records was done using the Inverse Distance Weighted (IDW) interpolation technique developed by Shepard [66] in equation (1). Due to its robustness, the IDW technique has been applied in several studies [67-71]. The missing rainfall depth/intensity $R_{M}$ at station $M$ for a given period was determined using rainfall values $R_{j}$ at the neighbouring stations $q$ of the same period: 
TABLE 1: Selected rainfall stations, their coordinates, and the data record period.

\begin{tabular}{lccccc}
\hline \multirow{2}{*}{$S / N$} & \multirow{2}{*}{ Station name } & \multicolumn{2}{c}{ Coordinate } & \multicolumn{2}{c}{ Data record } \\
& & Latitude & Longitude & From & To \\
\hline 1 & Bugiri & 0.57 & 33.75 & 1948 & 1975 \\
2 & Bugusege Coffee & 1.15 & 34.27 & 1948 & 1982 \\
3 & Research Station & & & & \\
4 & Butaleja Prison & 0.92 & 33.97 & 1948 & 1982 \\
5 & Dabani Catholic & 0.43 & 34.05 & 1948 & 1983 \\
6 & Imanyiro & 0.48 & 33.45 & 1948 & 1974 \\
7 & Sukulu VTRO & 0.62 & 34.17 & 1963 & 1987 \\
8 & Tororo & 0.68 & 34.17 & 1981 & 2009 \\
9 & Kibale VTC & 1.20 & 33.78 & 1948 & 1982 \\
\hline & Vukula & 0.95 & 33.58 & 1948 & 1980 \\
\hline
\end{tabular}

$$
R_{M}=\sum_{j=1}^{q} R_{j} \times d_{j}^{-\tau}\left(\sum_{j=1}^{q} d_{j}^{-\tau}\right)^{-1},
$$

where $d_{j}$ is the distance between station $M$ with the missing data record and that of the neighbouring station $q$ used for interpolation. $\tau$ is the power parameter which determines the dependability of the IDW interpolations. A small value of $\tau$ results in an average value considering all the neighbouring stations whereas a large value of $\tau$ results in the utilisation of only the nearest neighbouring stations ignoring input from the distant neighbouring stations [71, 72]. To minimise the interpolation errors, the value of $\tau=2$ is recommended for daily or monthly data, $\tau=3$ for hourly data, and $\tau=1$ for annual data. In this study, based on the recommendation by Goovaerts [73] and Lloyd [74], a value of $\tau=2$ was adopted.

Due to the lack of observed long-term evaporation and temperature data, the potential evapotranspiration PET used in this study was estimated. A number of methods for estimating PET exist and they are categorically based on the combined energy-mass balance (Food and Agricultural Organization of the United Nations (FAO) and Penman-Monteith method [75]), temperature (Hargreaves [76, 77], Thornthwaite [78], Hamon [79], Linacre [80], and Blaney-Criddle [81]), radiation (Abtew [82], Priestly-Taylor method [83], and Makkink [84]), and mass-transfer (Rohwer [85]). Because of its physical meaning, the Penman-Monteith method has attracted wide applications $[75,86,87]$, particularly in regions with available weather data, making it unique compared with other methods which may require local calibration [88]. The Hargreaves method necessitates only the measured minimum and maximum temperature data, is easy to use, and is unlikely to be affected when data is obtained from arid or semiarid, unirrigated sites than the Penman-Monteith method [89].

Seong et al. [87] compared five different methods in approximating PET including the Hargreaves [76, 77], Hamon [79], Thornthwaite [78], Priestley-Taylor [83], and Penman-Monteith [75]. The Hargreaves method yielded comparable results with the FAO Penman-Monteith method when applied to the Susquehanna River Basin in the northeastern United States [87]. Li et al. [86] applied both the Penman-Monteith and Hargreaves method in estimating PET for hydrological modelling. The Hargreaves method yielded remarkable streamflow simulation results when applied to the Ganjiang River Basin and was recommended to be an alternative to the Penman-Monteith method [86]. The choice of a PET method depends on the required temporal resolution, quality of the available weather data, and the required level of analysis [89]. Subsequently, Hargreaves and Allen [89] recommended the use of the Hargreaves method in situations where data quality is uncertain, and/or where historical weather data is missing. In the same line, the Hargreaves method was recently applied in a study [41] analysis of evapotranspiration in the region where the study area is located. Eventually, based on the analysis of the aforesaid PET methods, the lack of adequate weather data such as solar radiation, relative humidity and/or wind speed in the study area, and the coarse resolution of the available PET CRU TS v4 data [56], the Hargreaves method $[76,77]$ was adopted in this study. The PET $(\mathrm{mm} /$ day) was computed at each grid point using the following equation:

$$
\operatorname{PET}=0.0023\left(T_{\text {mean }}+17.8\right)\left(T_{\max }-T_{\min }\right)^{0.5} R a,
$$

where $R^{a}$ measures the extraterrestrial solar radiation in $\mathrm{W} / \mathrm{m}^{2}$ and this was estimated based on the location's latitude and the calendar day of the year, and $T_{\text {mean }}$ in ${ }^{\circ} \mathrm{C}$ is the mean temperature.

The daily PGF rainfall and PET at each grid point were transformed to other temporal resolutions including monthly, seasonal, and annual time series. Three seasons were considered including MAM, June-September (JJAS), and OND. The different temporal resolutions were used to analyse the high climatic variabilities. The MAM and OND seasons represent the rainy periods in each year while the JJAS represent the long dry period over the study area. The short dry period of January to February (JF) was not considered in this study. Similarly, at each rainfall station, annual and seasonal (MAM, JJAS, and OND) time series were extracted.

2.3. Trend Analyses. The linear trend slope $(m)$ was computed using Theil [90] and Sen [35] in the following equation:

$$
m=\operatorname{median}\left(\frac{x_{j}-x_{i}}{j-i}\right), \quad \forall i<j,
$$

where $x_{i}$ and $x_{j}$ are the corresponding $i^{\text {th }}$ and $j^{\text {th }}$ observations, respectively.

The significance of the trend was tested using the CSD method $[21,27,40]$. To apply the CSD method, the given dataset of size $n$ was first transformed into another series in terms of the difference $d_{i}$ between the exceedance and nonexceedance counts of data points such that

$$
d_{i}=u_{i}-v_{i} \quad \text { for } 1 \leq i \geq n,
$$

where $u_{i}$ is the number of times each data point is exceeded and $v_{i}$ is the number of times each data point exceeds others. 
The CSD trend statistic $T$ is computed using the following equation [21]:

$$
T=\frac{6}{\left(n^{3}-n\right)} \sum_{i=j}^{n-1} \sum_{i=1}^{j} d_{i} .
$$

Positive and negative values of $T$ indicate increasing and decreasing trends, respectively. The distribution of $T$ is approximately normal with the mean of zero and variance being given by $V=1 /(n-1)[21,27]$.

The standardized CSD trend statistic $Z$ with the mean of zero and a standard deviation of one can be given by the following equation:

$$
Z=\frac{T}{\sqrt{(n-1)^{-1} \times \gamma}},
$$

where $\gamma$ represents the factor to correct the variance of $T$ from the effect of autocorrelation (see Onyutha [27] and Onyutha [91] for details). If $Z_{\alpha / 2}$ is the standard normal variate, the null hypothesis $H_{\mathrm{o}}$ (no trend) was rejected at $\alpha$ if $|Z| \geq\left|Z_{\alpha / 2}\right|$; otherwise, the $H_{\mathrm{o}}$ was not rejected.

\subsection{Correlation between PGF-Gridded Rainfall and Observed} Rainfall. To compute variability using the CSD method, the given data $X$ is divided into subsets each starting from the $p^{\text {th }}$ to the $f^{\text {th }}$ value of $X$ (equation (7)). To each subseries, the subtrend statistic $Z$ is computed using equation (6). To do so, a time slice of length $h$ is moved from the beginning to the end data record. For the selected $h, s=0.5 \times(h+1)$ and $s=$ $0.5 \times h$ in the cases when $h$ is odd and even, respectively, such that [46]

$$
Z_{i}^{h}=f\left(x \subset X \mid x_{p} \leq x \leq x_{f}\right), \quad \text { for } t=1,2, \ldots
$$

where $Z_{i}$ is the $i^{\text {th }}$ value of $Z$, while the terms $p$ and $f$ can be given by

$$
\left.\begin{array}{l}
\text { if } t<s, \quad p=1, \quad f=s+t-s-1 \\
\text { if } t \geq s \text { and } i \leq(n-s), \quad p=t-s+1, \quad f=t+s \\
\text { if } t>(n-s) \text { and } t \leq n, \quad p=t-s+1, \quad f=n
\end{array}\right\} \text {. }
$$

The values of $Z_{i}$ (equation (7)) are plotted against the corresponding $i^{\text {th }}$ data year. The $Z=0$ line becomes the reference representing the data with completely no trend. Variability in the data is considered in terms of the occurrences of the positive and negative subtrends. The $(100-\alpha) \%$ Confidence Interval (CI) limits are constructed in terms of $Z_{\alpha / 2}$ at $\alpha$. The $H_{\mathrm{o}}$ (natural randomness) is rejected if the scatter falls outside the $(100-\alpha) \% \mathrm{CI}$ limits or if $|Z|>Z_{\alpha / 2}$ at $\alpha$; otherwise, the $H_{\mathrm{o}}$ is not rejected.

A comparison of the variability from PGF and observed rainfall was made at both seasonal (MAM, JJAS, and OND) and annual time series. This involved testing the $H_{\mathrm{o}}$ (no correlation between observed and PGF rainfall). Due to the lack of observed evaporation data, validation of PGF data was done using only the observed rainfall from the selected stations.

\section{Results and Discussion}

3.1. Statistical Trend Analyses on Rainfall. Figure 2 shows the statistical trend results in annual and seasonal rainfall. Based on Figure 2(a), the entire area had only a positive significant trend $\left(H_{0}\right.$ rejected $)$ at a level of $5 \%$ in the annual and MAM rainfall. The study by Majaliwa [26] reported similar results for the MAM season from 1980 to 2010. During the OND season, the study area had only a negative insignificant trend in rainfall, except the far western part outside the study area that experienced a positive significant trend $\left(H_{0}\right.$ rejected) (Figure 2(b)). Apart from the south as well as the southeast region characterised by a negative insignificant trend during the JJAS season, the rest of the area had a negative significant trend $\left(H_{0}\right.$ rejected) at the 5\% level (Figure 2(c)). These results are consistent with the findings from the study by Nsubuga et al. [92]. Generally, whereas the entire catchment experienced a significant increase in the annual and MAM rainfall and a significant decrease during the JJAS season, the OND rainfall in most of the regions was not statistically significant at the 5\% level. Largely, the results are consistent with the findings from the previous study by Onyutha [27] that considered all Uganda and reported results at an annual scale.

Positive (negative) rainfall trends result in different parts of the study area becoming wetter (drier). Consequently, there are alterations in the hydrological processes which affect the frequency, severity, and/or intensity of extreme weather events like erratic rainfall, landslides, floods, prolonged dry spell, and drought. These events destroy infrastructures and lead to food insecurity and a reduction of the general incomes of the community. Therefore, with such disastrous events, well-thought adaptation strategies developed based on an integrated understanding of the extreme weather events and social perception are vital [93]. In addition, the presence of trends and shifts in the rainfall embraces the need to consider nonstationarity [94], while planning, designing, and operating water infrastructures that can be affected by the weather events (like floods).

3.2. Statistical Trend Analyses on Evapotranspiration. The trends in annual and seasonal evapotranspiration are shown in Figure 3. The western region (close but outside the catchment), as well as the northeast part far outside the catchment, had a positive significant trend $\left(H_{0}\right.$ rejected) in the annual evapotranspiration (Figure 3(a)). The rest of the study area experienced a negative insignificant trend at the $5 \%$ level. Like the annual evapotranspiration, the western part (close but outside the catchment), as well as the northeast and northwest regions, had a positive significant trend $\left(H_{0}\right.$ rejected) in the OND evapotranspiration. The rest of the catchment had a positive insignificant trend at the $5 \%$ level as shown in Figure 3(b). During the JJAS season, the region near the southeast and the far western parts of the study area (approximately $30 \mathrm{~km}$ away) had a negative significant trend $\left(H_{0}\right.$ rejected) in the evapotranspiration (Figure 3(c)). The rest of the study area experienced a positive but insignificant trend at the $5 \%$ level. 

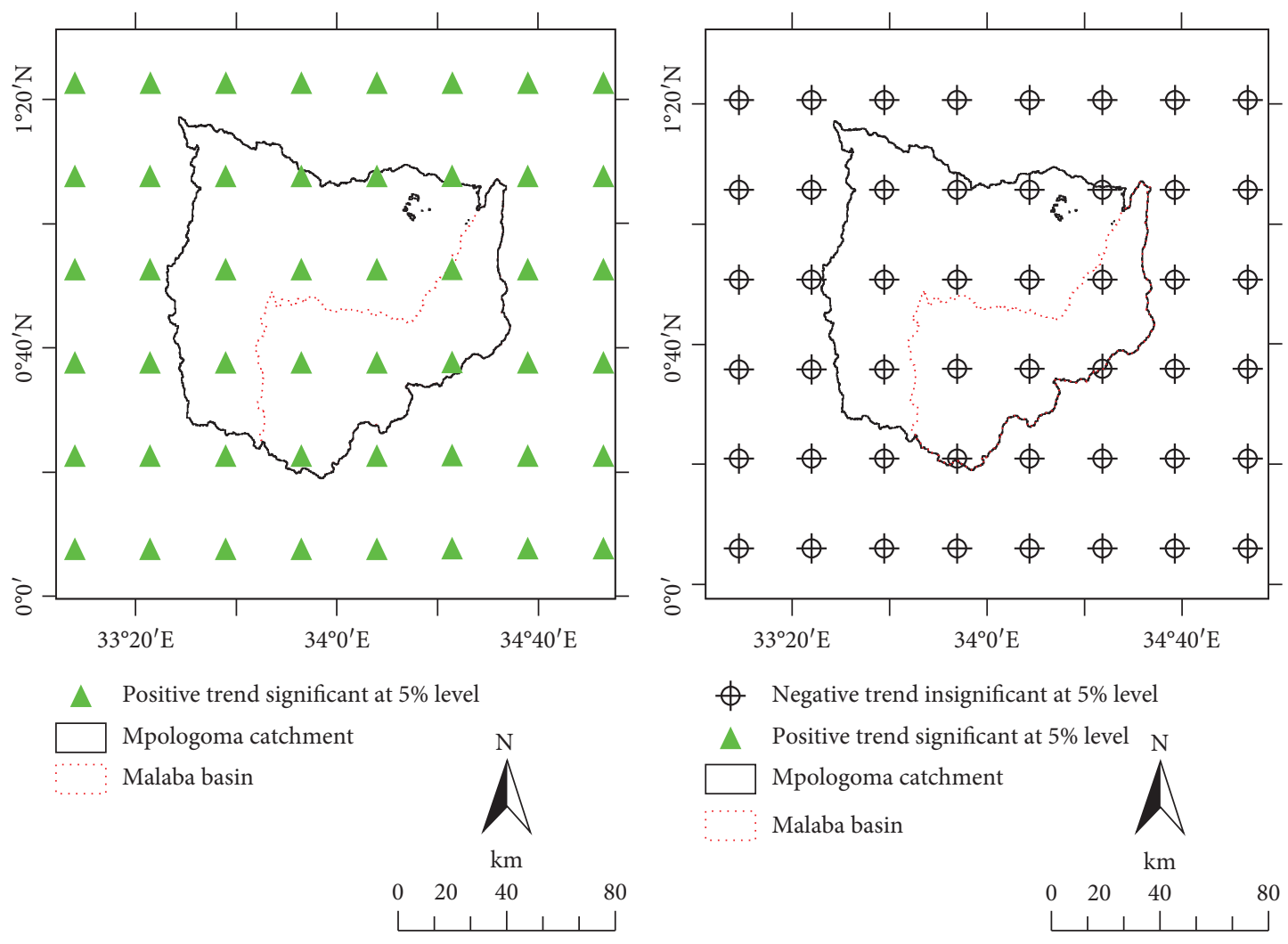

(a)

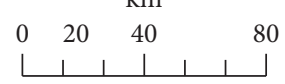

(b)

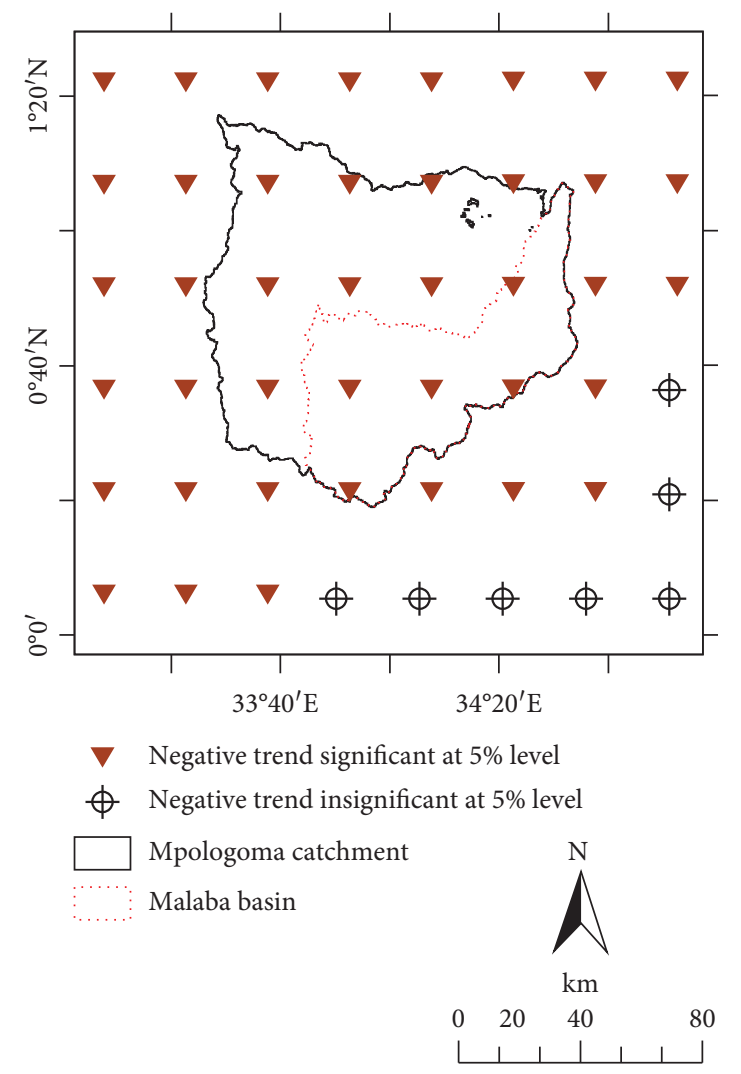

(c)

Figure 2: Trend on rainfall: (a) annual/MAM, (b) OND, and (c) JJAS. 


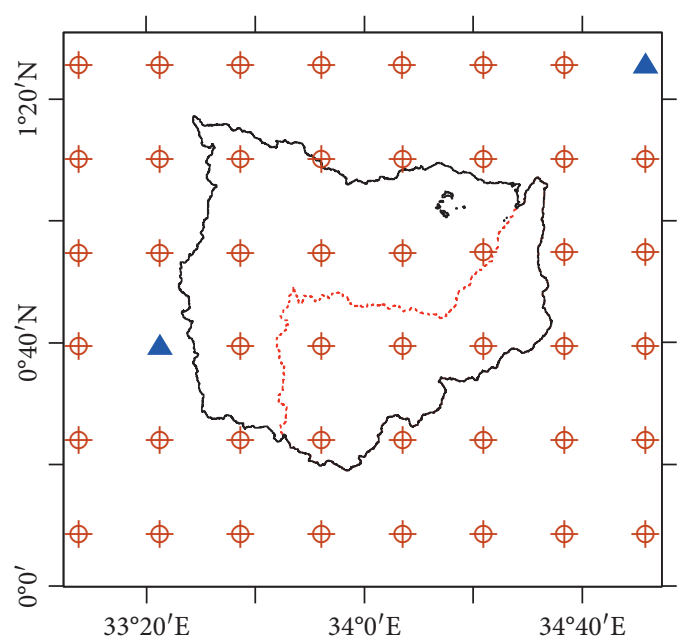

$\phi$ Negative trend insignificant at $5 \%$ level

- Positive trend significant at $5 \%$ level

Malaba basin

Mpologoma catchment

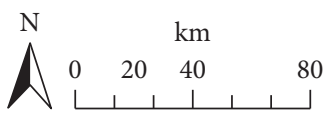

(a)

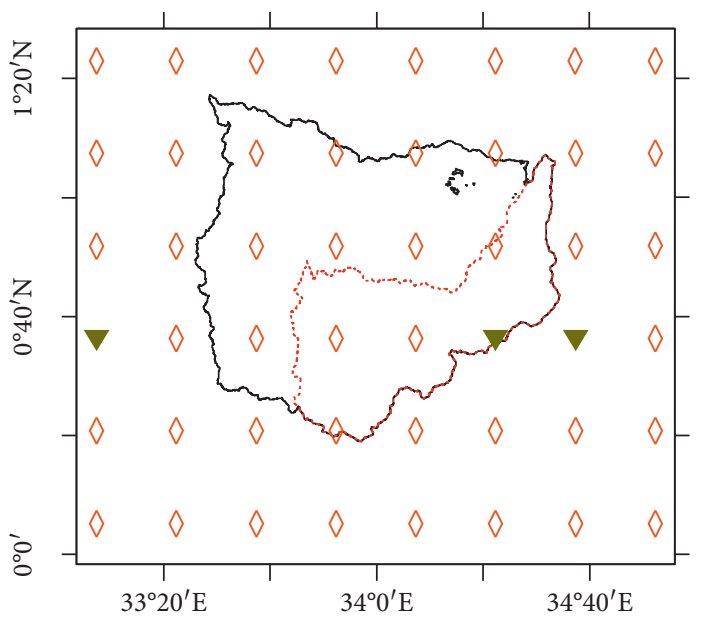

$\diamond \quad$ Positive trend insignificant at $5 \%$ level

- Negative trend significant at $5 \%$ level

Malaba basin

Mpologoma catchment

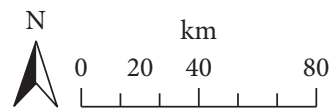

(c)

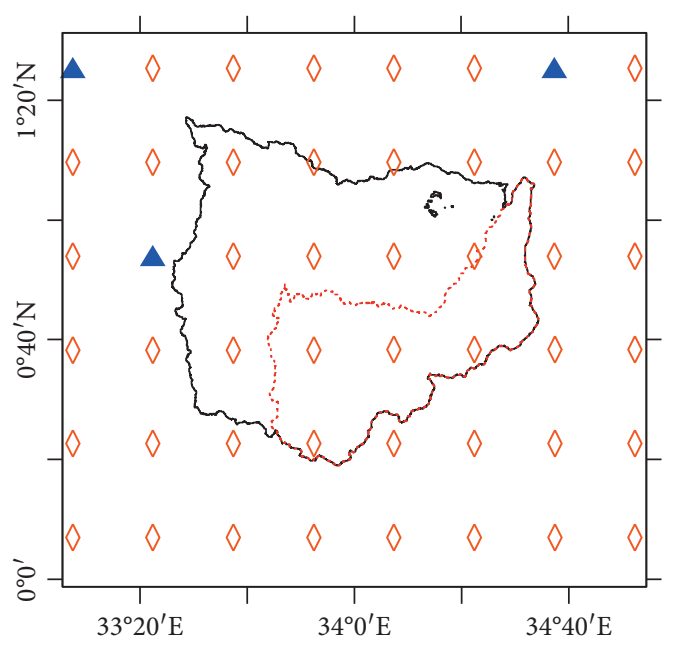

$\diamond$ Positive trend insignificant at $5 \%$ level

- Positive trend significant at $5 \%$ level

Malaba basin

Mpologoma catchment

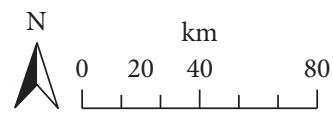

(b)

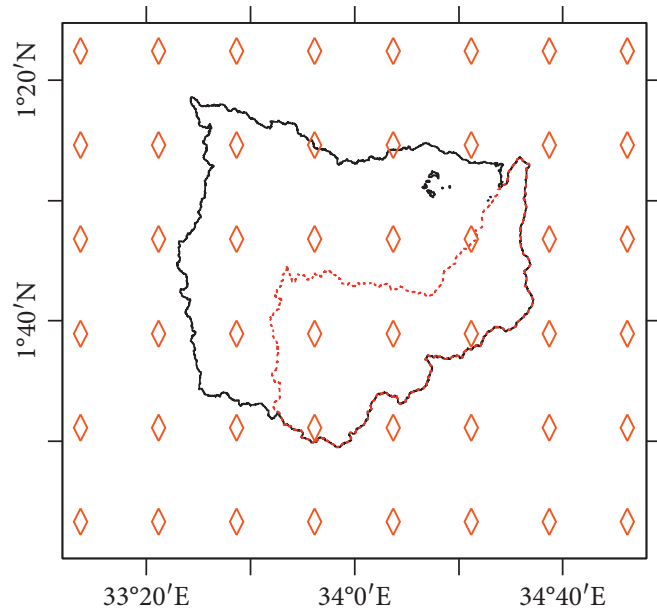

$\diamond \quad$ Positive trend insignificant at $5 \%$ level

Malaba basin

Mpologoma catchment

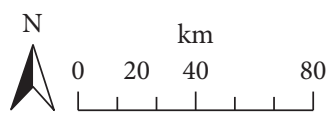

(d)

Figure 3: Trend on evapotranspiration: (a) annual, (b) OND, (c) JJAS, and (d) MAM.

During the MAM season, the entire study area exhibited only a positive insignificant trend in the evapotranspiration (Figure 3(d)).

In conclusion, the evapotranspiration over the entire area exhibited an increase at the seasonal scales although not significant at the $5 \%$ level. A similar result was found by Onyutha [21], which indicated an increase of evapotranspiration over all Uganda. Similarly, the results were in agreement with the findings from Alemu et al. [20]. The increase in evapotranspiration could be attributed to the increasing temperature as well as the varying rainfall from region to region over the study area. In addition, for the entire period (1948 to 2016), there was no negative trend in the OND and MAM evapotranspiration (Figures 3(b) and $3(d)$ ). An increase in evapotranspiration over the study area at the seasonal scales although not significant would imply potential impacts on the soil water balance and harvest in the agricultural sector. Consequently, this could result in internment drought events leading to water stresses, crop failure, and, hence, food insecurity [95]. 
3.3. Spatiotemporal Variability Analyses on Rainfall. Spatiotemporal variability is explained in terms of oscillation highs (OHs), which indicate a variable higher than the longterm mean, and oscillation lows (OLs), which designate a variable below the long-term mean. The long-term mean corresponds to the trend statistic $Z$ value of zero. The null hypothesis $H_{0}$ (natural randomness) is not rejected (rejected) if variability statistics fall inside (outside) the $95 \%$ confidence interval. When $H_{0}$ is not rejected (rejected), this indicates that $\mathrm{OH}$ and/or OL is insignificant (significant). Figures 4-6 show the differences in spatiotemporal variation in the rainfall across the study area at annual and seasonal scales.

The entire study area experienced both insignificant $\mathrm{OH}$ and OL (Figure $4(\mathrm{a})$ ) of a generally similar pattern with a weak frequency fluctuation (Figures $4(\mathrm{~b})-4(\mathrm{e})$ ) at annual and OND season. Previously, the study by Nsubuga et al. [92] reported similar results. In addition, these results are consistent with the findings from Onyutha [27]. Rainfall was characterised more by a decrease than an increase from the early 1960s till around 2005. However, in the 1950s as well as from the mid-2000s till the end of the study period (2016), rainfall was above the long-term mean (Figures 4(b)-4(e)).

Similarly, Figure 5(a)shows that the JJAS rainfall over the entire study area was characterised by both insignificant $\mathrm{OH}$ and OL. Rainfall was above the long-term mean in the 1950s, whereas from the early 1960 s till the end of the study period, rainfall was below the reference (Figures 5(b)-5(e)).

Figure 6(a) shows the significant $\mathrm{OH}$ in the northern region, while the southern region of the catchment had both insignificant $\mathrm{OH}$ and $\mathrm{OL}$ during the MAM season. Similar to the annual and OND temporal variation, the rainfall was above the long-term mean in the 1950s as well as from around 2006 till the end of the study period (Figures 6(b)$6(\mathrm{e}))$. The results are in agreement with the findings from Majaliwa et al. [26].

OHs (OLs) in rainfall indicate floods/landslides (drought) conditions and these may increase in future should the rainfall variability continue with the same temporal pattern. The finding from Ongoma et al. [96] established that the study area exhibited high values of simple daily intensity index which could be associated with recurrent floods and landslides. The study area mainly suffers from prolonged and severe floods/landslides conditions especially during the MAM season which destroy properties and cause loss of lives. It could be possible that the severe floods and landslides of March 2010 that killed over 400 people, displacing 5,000 people in Bududa district with over 33,000 households being affected in Butaleja, were due to an increase in rainfall.

3.4. Spatiotemporal Variability Analyses on Evapotranspiration. Figures 7-10 show the differences in spatial variation in the annual and seasonal evapotranspiration across the study area.

On the annual scale, some regions in the north, as well as areas near the southeast, had significant $\mathrm{OH}\left(H_{0}\right.$ rejected). The far northeast and southeast regions (outside the study area) experienced significant OL $\left(H_{0}\right.$ rejected). The rest of the area experienced both insignificant $\mathrm{OH}$ and $\mathrm{OL}$ (Figure 7(a)). From Figures 7(b)-7(e), annual evapotranspiration was characterised by both increase and decrease for the whole study period but the northern region exhibited more of an increase in the mid-1970s till the late 1980s (Figures 7(b)-7(d)).

Figure 8(a) shows that only the southern region of the catchment and an area approximately $30 \mathrm{~km}$ north of the study area experienced significant $\mathrm{OL}$ and $\mathrm{OH}$, respectively, during the OND season. The rest of the catchment had both insignificant $\mathrm{OH}$ and $\mathrm{OL}$ during the $\mathrm{OND}$ season. The temporal variation of OND evapotranspiration was characterised by both increase and decrease but more pronounced increase (Figures $8(\mathrm{~b})-8(\mathrm{e})$ ).

Figure 9(a) shows that, during the JJAS season, the southeast region had significant $\mathrm{OH}$. The southwest/western region outside the catchment was characterised by both significant $\mathrm{OH}$ and $\mathrm{OL}$. However, the rest of the catchment had both insignificant $\mathrm{OH}$ and $\mathrm{OL}$ in the JJAS evapotranspiration. Evapotranspiration was generally above the reference except from the mid-1990s till the end of the study period when it was more below the long-term mean (Figures 9(b)-9(e)).

For the MAM season, significant OL was in the west, east, southeast, and far northeast (outside of the catchment) regions (Figure 10(a)). The rest of the area experienced both insignificant $\mathrm{OH}$ and OL. MAM evapotranspiration exhibited both an increase and decrease going above (below) the long-term mean for the entire study period (Figures 10(b)-10(e)).

3.5. Correlation between PGF-Gridded and Observed Rainfall. The correlation of the extracted anomalies between PGF and observed rainfall is shown statistically in Table 2 . The correlation is also presented graphically in Figures 11-14 at both annual and seasonal (OND, MAM, and JJAS) time series. Similarly, the critical values of the coefficient of correction at each station are indicated in Table 2.

From Table 2, except station 1 where $H_{0}$ was not rejected at all time scales, there was a rejection of $H_{0}$ on at least one time scale for the remaining stations. For station $4, H_{0}$ was rejected at all the four time scales. Only station 9 had a negative significant correlation at the annual scale. Stations 5 and 9 exhibited negative correlations during the OND season, with station 5 having a significant negative correlation. Stations 1, 2, 6, and 9 had also negative correlations during the MAM season. All stations except 1 and 5 had negative correlations during the JJAS season, with stations 3 and 4 displaying significant correlations. The positive (negative) correlation implies that when the observed rainfall displayed a rise (reduction) over a certain period, the PGF rainfall exhibited a decrease (an increase).

From Figures 11-14, it is shown that the PGF rainfall overrates and/or underestimates the oscillations highs and lows from the observed rainfall at different time scales. These results are in agreement with the findings from Onyutha [27]. The results presented in Figures 11-14 and Table 2 


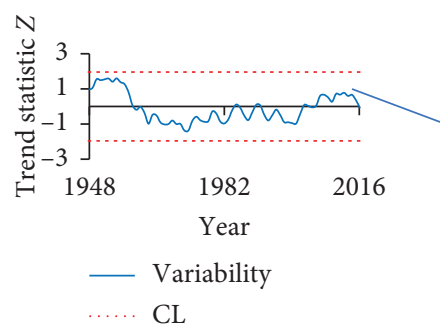

(b)
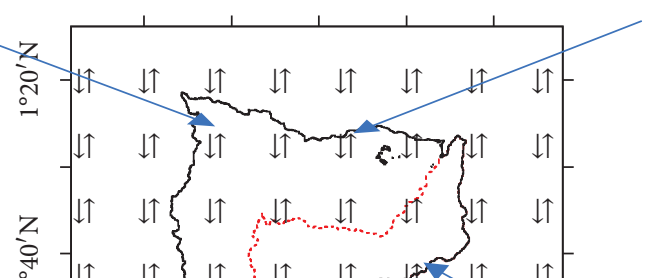

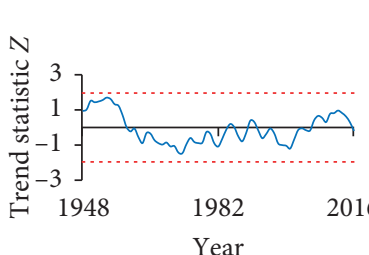

2016

— Variability CL

(c)

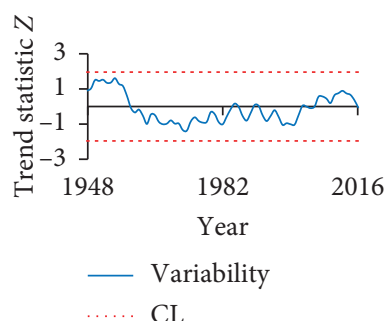

(d)

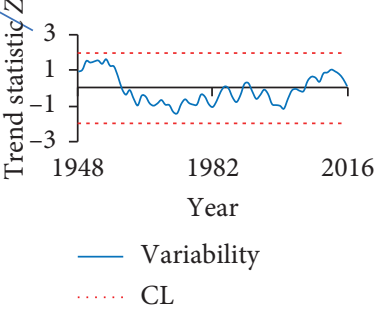

(e)

FIgURE 4: Spatial differences in the significance of rainfall variability (a) and temporal variability in annual and OND rainfall (b-e) at different locations of the study area.

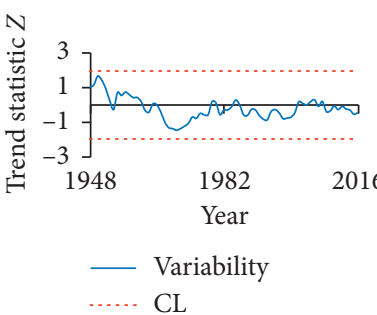

(b)

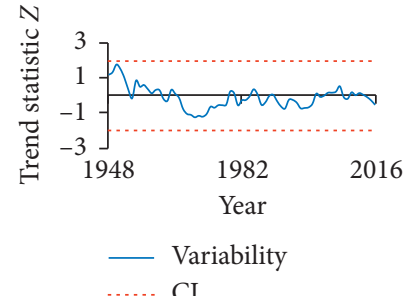

(c) (a)

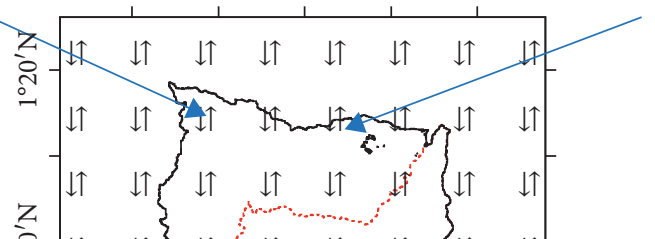

$$
\begin{aligned}
& \text { Z } \\
& \text { 우 } \\
& \text { ○ }
\end{aligned}
$$

$\downarrow \uparrow \quad$ Both $\mathrm{OH}$ and $\mathrm{OL}$ insignificant at $5 \%$ level

$\square$ Mpologoma catchment

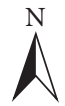

$\mathrm{km}$

$\begin{array}{llll}0 & 20 & 40 & 80\end{array}$ 


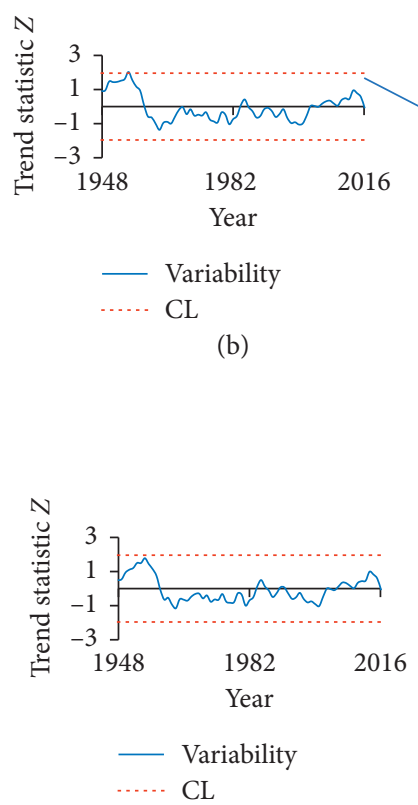

(c)

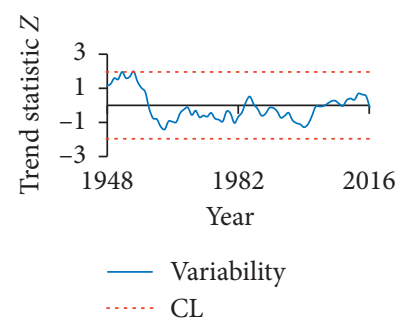

(d)

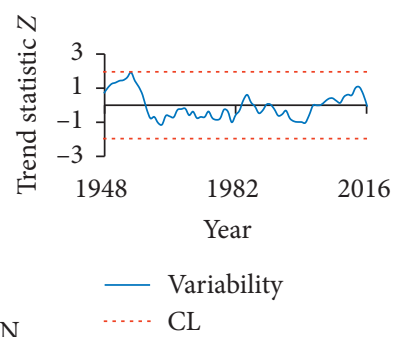

(e) $\square$ Mpologoma catchment

Malaba basin

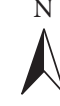

$\mathrm{km}$

(a)

FIGURE 6: Spatial differences in the significance of rainfall variability (a) and temporal variability in MAM rainfall (b-e) at different locations of the study area.

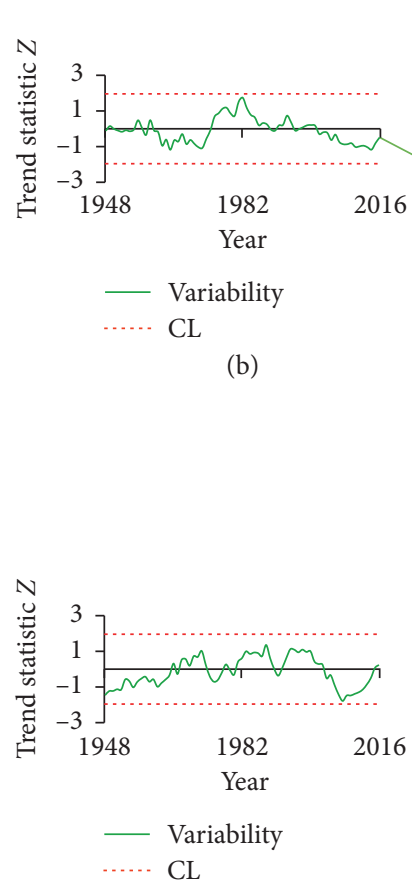

(c)

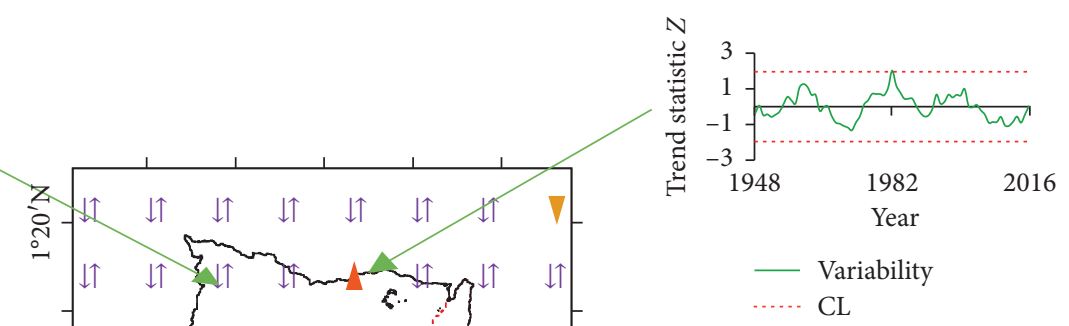

(d)

(a)

FIGURE 7: Spatial differences in the significance of annual evapotranspiration variability (a) and temporal variability in annual evapotranspiration (b-e) at different locations of the study area. 


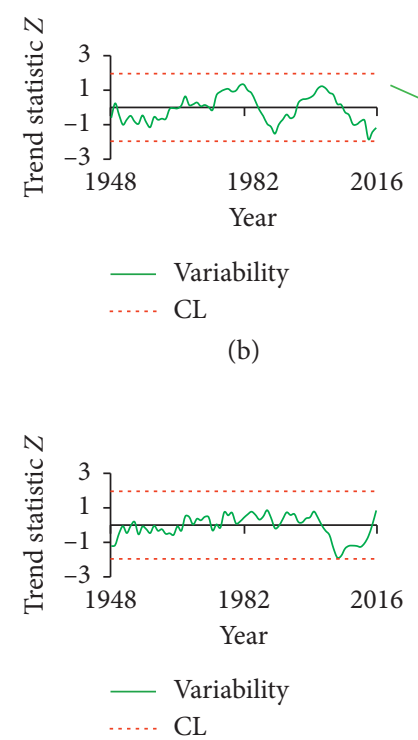

(c)

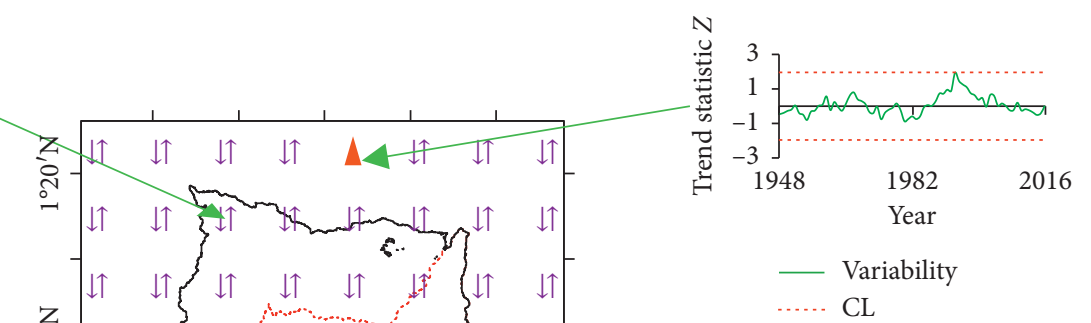

(d)

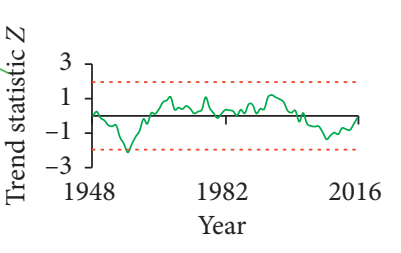

A OH significant at $5 \%$ level

$\checkmark$ OL significant at $5 \%$ level

ariability

Malaba basin

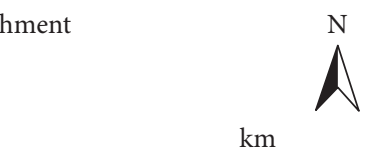

$\begin{array}{lll}0 & 20 & 40\end{array}$

(e)

(a)

FIGURE 8: Spatial differences in the significance of evapotranspiration variability (a) and temporal variability (b-e) in OND evapotranspiration at different locations of the study area.

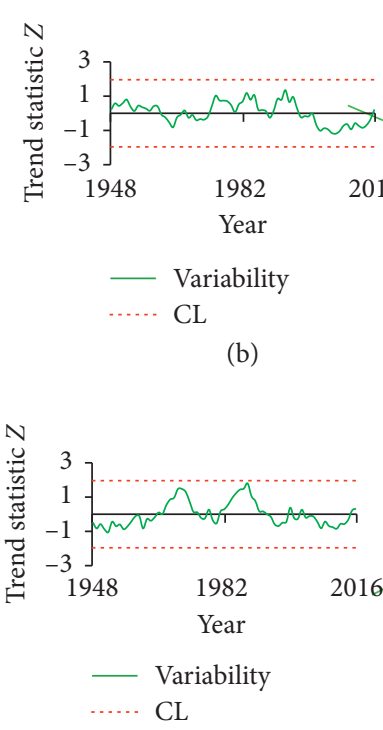

(c)

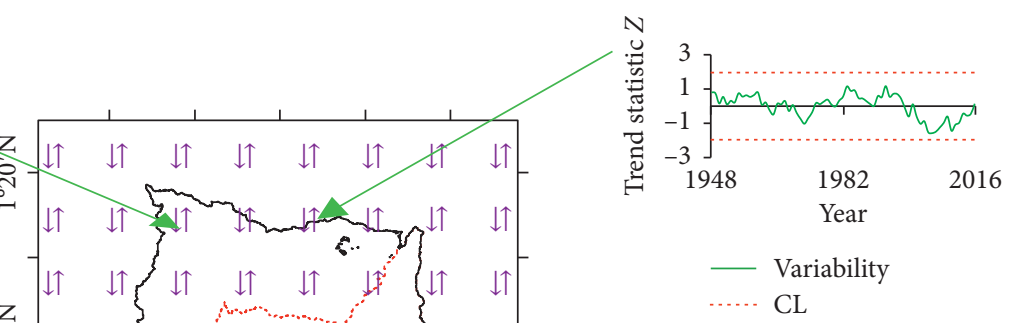

(d)

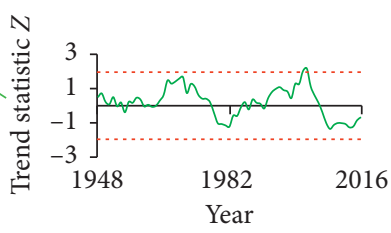

$\downarrow \uparrow \quad$ Both $\mathrm{OH}$ and $\mathrm{OL}$ insignificant at $5 \%$ level

$\Lambda \mathrm{OH}$ significant at $5 \%$ level

V OL significant at $5 \%$ level

Mpologoma catchment

Malaba basin

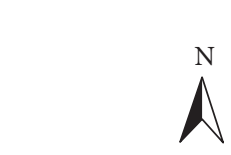

_ Variability

…. CL

(e)

(a)

FIGURE 9: Spatial differences in the significance of evapotranspiration variability (a) and temporal variability (b-e) in JJAS evapotranspiration at different locations of the study area. 


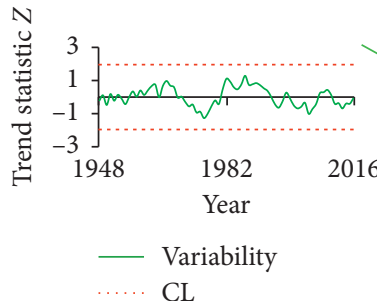

(b)

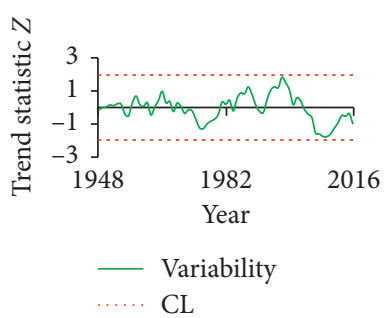

(c)

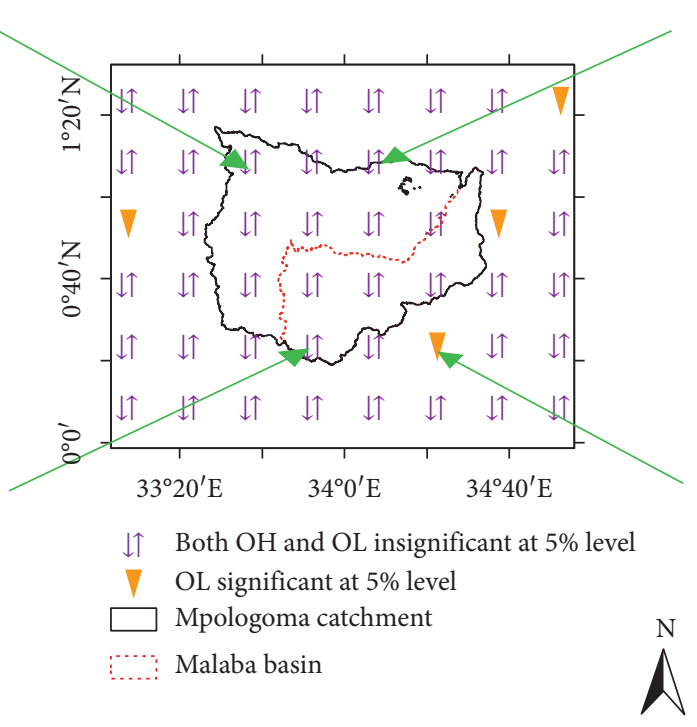

$\mathrm{km}$

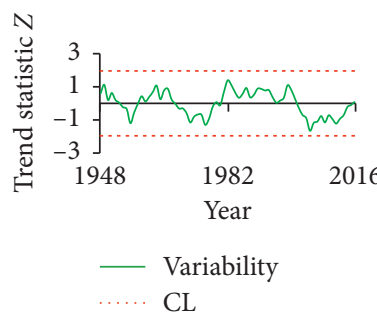

(d)

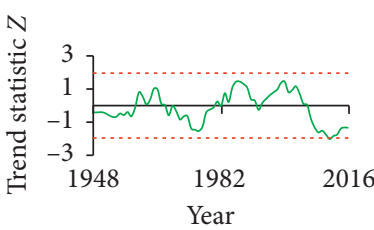

_ Variability

CL

(e)

$\begin{array}{llll}0 & 20 & 40 \quad 80\end{array}$

(a)

FIGURE 10: Spatial differences in the significance of evapotranspiration variability (a) and temporal variability (b-e) in MAM evapotranspiration at different locations of the study area.

TABLE 2: Correlation between PGF-gridded rainfall and observed rainfall at the selected stations for annual and seasonal (OND, JJAS, and MAM) time series.

\begin{tabular}{|c|c|c|c|c|c|c|}
\hline \multirow{2}{*}{$S / N$} & \multirow{2}{*}{ Station name } & \multicolumn{4}{|c|}{ Correlation coefficient } & \multirow{2}{*}{ Corr. Crit } \\
\hline & & Annual & OND & JJAS & MAM & \\
\hline 1 & Bugiri & 0.21 & 0.19 & 0.12 & -0.21 & 0.37 \\
\hline 2 & Bugusege Coffee Research Station & $0.44^{*}$ & 0.11 & -0.03 & -0.02 & 0.33 \\
\hline 3 & Butaleja Prison & 0.20 & 0.22 & $-0.45^{*}$ & 0.25 & 0.33 \\
\hline 4 & Dabani Catholic & $0.40^{*}$ & $0.55^{*}$ & $-0.35^{*}$ & $0.44^{*}$ & 0.33 \\
\hline 5 & Imanyiro & 0.33 & -0.53 & 0.16 & $0.68^{*}$ & 0.38 \\
\hline 6 & Sukulu VTRO & $0.52^{*}$ & 0.30 & -0.31 & -0.12 & 0.40 \\
\hline 7 & Tororo & 0.34 & $0.45^{*}$ & -0.05 & $0.64^{*}$ & 0.37 \\
\hline 8 & Kibale VTC & 0.24 & $0.43^{*}$ & -0.33 & 0.17 & 0.33 \\
\hline 9 & Vukula & $-0.35^{*}$ & -0.02 & -0.31 & -0.30 & 0.34 \\
\hline
\end{tabular}

Corr. Crit: correlation critical value at the $5 \%$ significance level. ${ }^{*}$ Those values of the correlation coefficient in the table indicate that $H_{0}$ (no correlation) was rejected at the $5 \%$ significance level, implying a significant correlation.

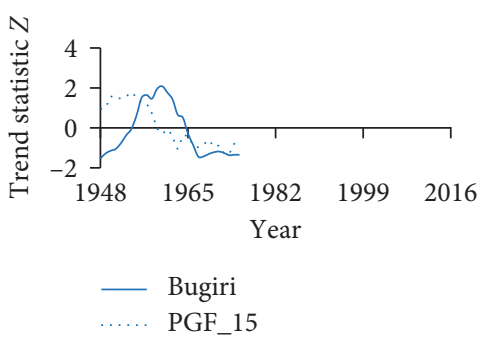

(a)

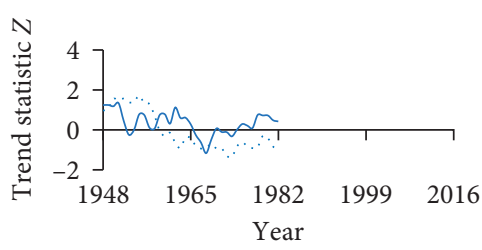

_ Bugusege coffee res stat. PGF_35

(b)

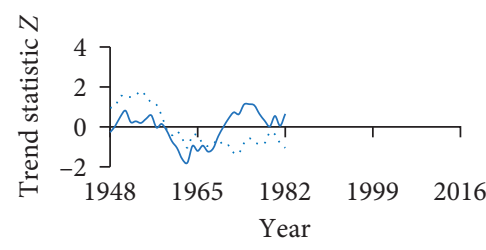

Butaleja prison PGF_22

(c)

Figure 11: Continued. 


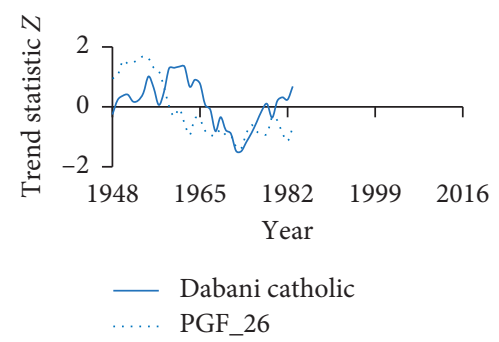

(d)

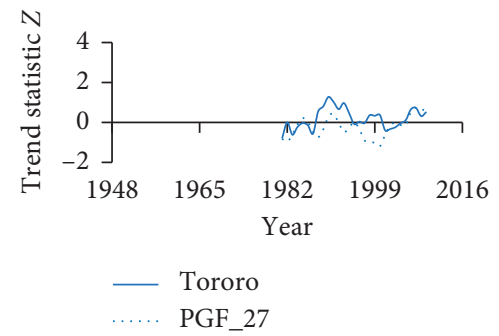

(g)

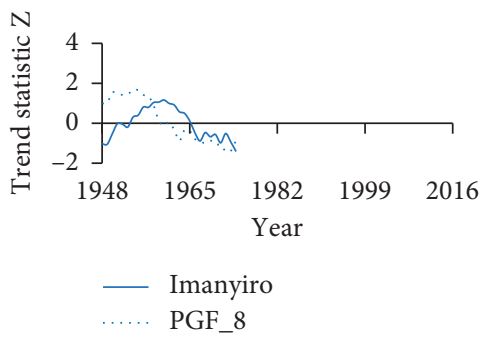

(e)

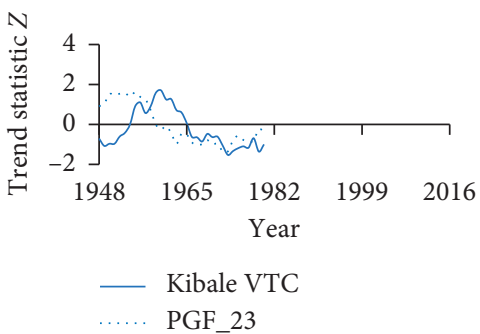

(h)

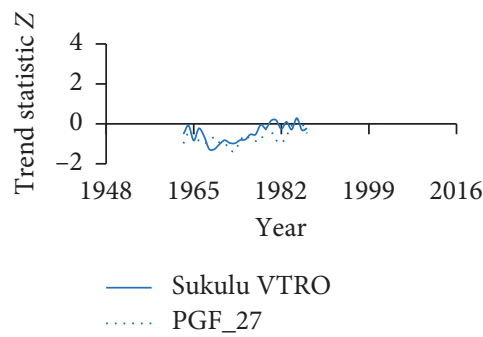

(f)

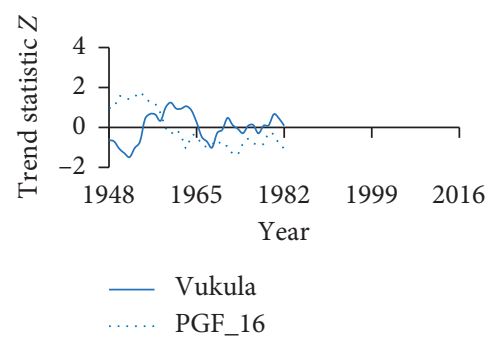

(i)

FIgURe 11: Variability of annual PGF and observed rainfall at stations (a) 1, (b) 2, (c) 3, (d) 4, (e) 5, (f) 6, (g) 7, (h) 8, and (i) 9.

TABle 3: Trend from observed and nearby PGF series at annual and seasonal scales.

\begin{tabular}{lcccccccccc}
\hline \multirow{2}{*}{ S/N } & Station & \multicolumn{2}{c}{ Annual } & \multicolumn{2}{c}{ OND } & \multicolumn{2}{c}{ JJAS } & \multicolumn{2}{c}{ MAM } \\
& & $Z$ & $p$ & $Z$ & $p$ & $Z$ & $p$ \\
\hline \multirow{2}{*}{1} & Bugiri & $2.50^{*}$ & $0.012^{*}$ & 1.73 & 0.083 & 0.58 & 0.564 & 0.19 & 0.847 \\
& PGF_15 & 1.35 & 0.178 & 0.96 & 0.336 & 0.96 & 0.336 & $3.27^{*}$ & $0.001^{*}$ \\
2 & Bugusege Coffee Research Station & 0.00 & 1.000 & 1.71 & 0.086 & 0.69 & 0.493 & 0.34 & 0.732 \\
& PGF_35 & $2.06^{*}$ & $0.040^{*}$ & 0.69 & 0.493 & 0.69 & 0.493 & $2.74^{*}$ & $0.006^{*}$ \\
3 & Butaleja Prison & 0.34 & 0.732 & 1.71 & 0.086 & 0.69 & 0.493 & $2.74^{*}$ & $0.006^{*}$ \\
& PGF_22 & 1.71 & 0.086 & 0.34 & 0.732 & 0.34 & 0.732 & $2.74^{*}$ & $0.006^{*}$ \\
4 & Dabi Catholic & 0.51 & 0.612 & 1.86 & 0.063 & 0.51 & 0.612 & 1.18 & 0.237 \\
& PGF_26 & 0.85 & 0.398 & 0.85 & 0.398 & 0.17 & 0.866 & $3.55^{*}$ & $0.001^{*}$ \\
5 & Imanyiro & 1.57 & 0.117 & 0.78 & 0.433 & $2.35^{*}$ & $0.019^{*}$ & 0.39 & 0.695 \\
& PGF_8 & 0.78 & 0.433 & 0.39 & 0.695 & 1.57 & 0.117 & $3.14^{*}$ & $0.002^{*}$ \\
6 & Sukulu VTRO & 0.41 & 0.683 & 0.00 & 1.000 & 0.41 & 0.683 & 0.41 & 0.683 \\
& PGF_27 & 0.82 & 0.414 & 1.22 & 0.221 & 0.00 & 1.000 & 1.63 & 0.102 \\
7 & Tororo & 0.38 & 0.705 & 0.38 & 0.705 & 0.38 & 0.705 & 0.38 & 0.705 \\
& PGF_27 & 1.89 & 0.059 & 0.00 & 1.000 & 0.76 & 0.450 & 1.51 & 0.131 \\
8 & Kibale VTC & 1.41 & 0.157 & 0.71 & 0.480 & 1.77 & 0.077 & 0.35 & 0.724 \\
& PGF_23 & 1.77 & 0.077 & 0.71 & 0.480 & 0.71 & 0.480 & $3.18^{*}$ & $0.001^{*}$ \\
9 & Vukula & 1.71 & 0.086 & 1.37 & 0.170 & 0.34 & 0.732 & 1.71 & 0.086 \\
& PGF_16 & 1.71 & 0.086 & 0.34 & 0.732 & 0.34 & 0.732 & $2.74^{*}$ & $0.006^{*}$ \\
\hline
\end{tabular}

*Those values of $Z$ and $p$ in the table indicate that $H_{0}$ (no trend) was rejected at the $5 \%$ significance level.

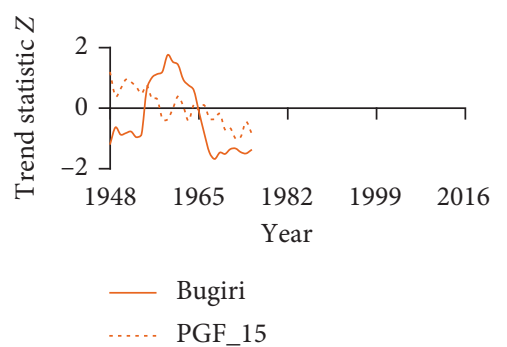

(a)

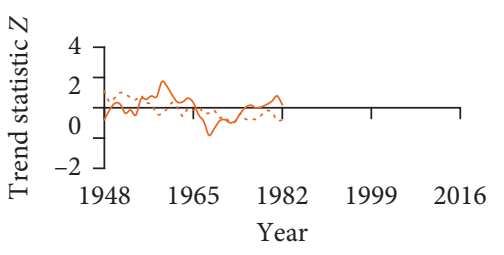

- Bugusege coffee res stat.

(b)

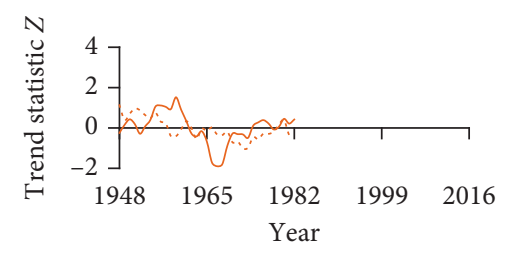

Butaleja prison PGF_22

(c)

FIgURe 12: Continued. 


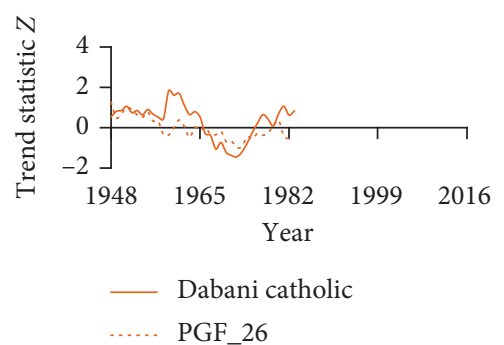

(d)

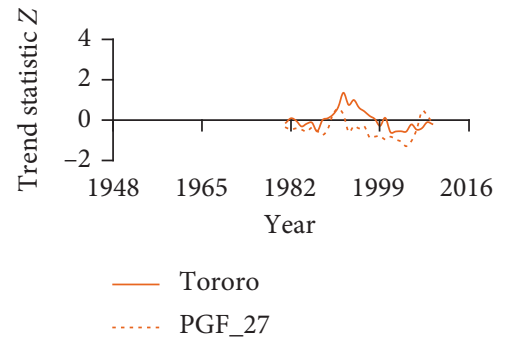

(g)
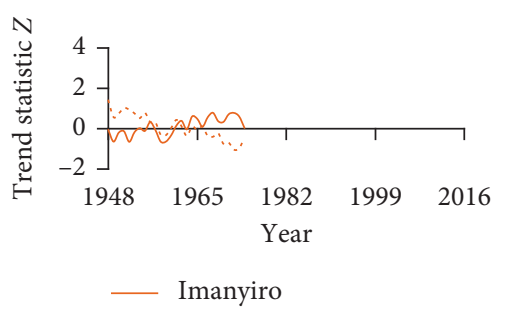

PGF_8

(e)

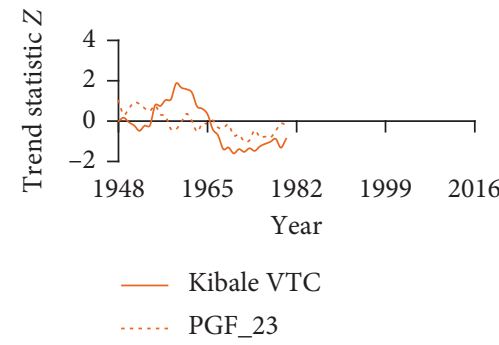

(h)

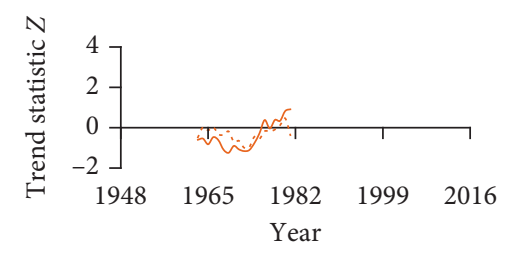

— Sukulu VTRO

..... PGF_27

(f)

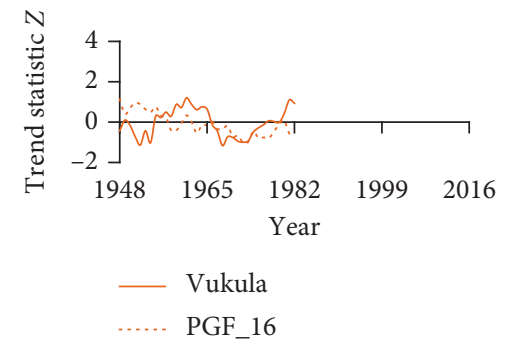

and (i)

FIGURE 12: Variability of OND PGF and observed rainfall at stations (a) 1, (b) 2, (c) 3, (d) 4, (e) 5, (f) 6, (g) 7, (h) 8, and (i) 9.

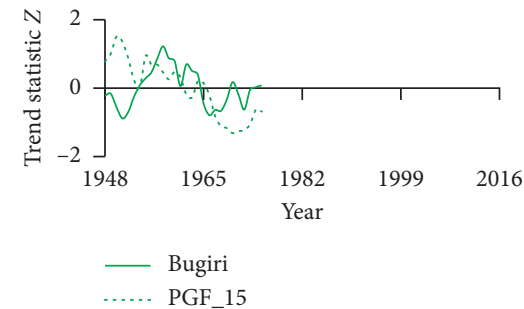

(a)

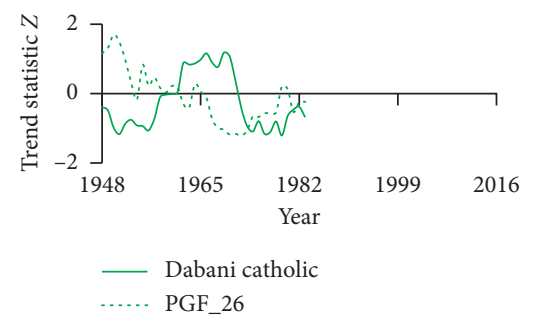

(d)

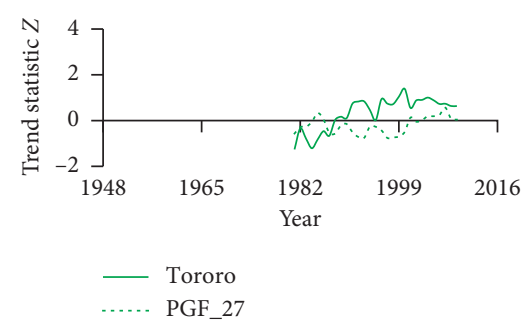

(g)

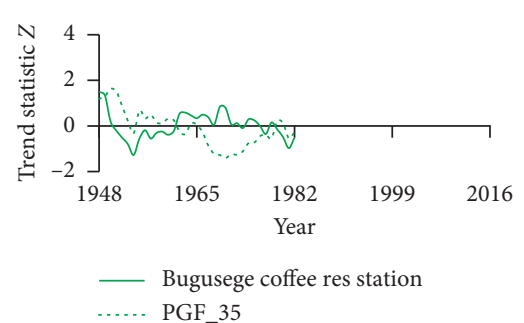

(b)

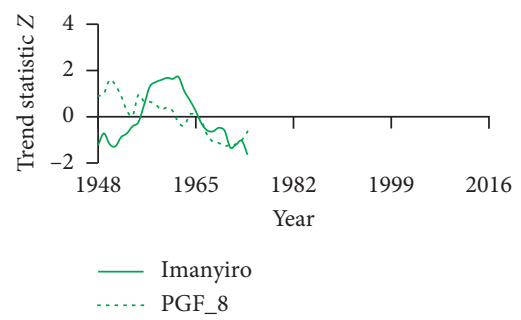

(e)

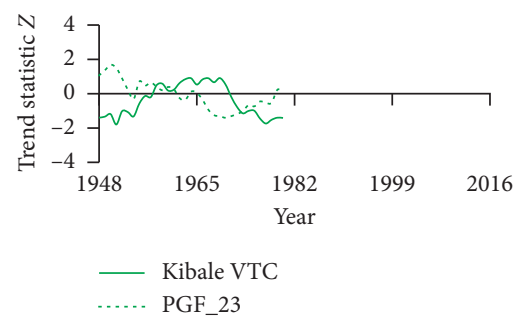

(h)

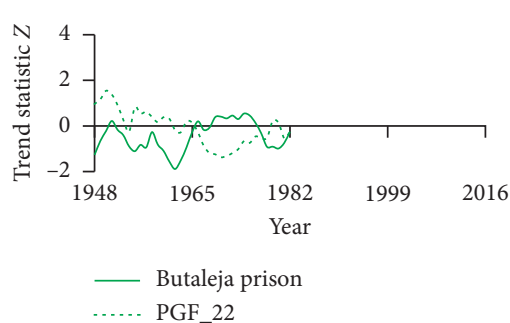

(c)

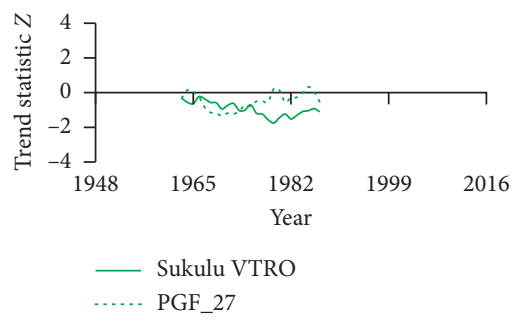

(f)

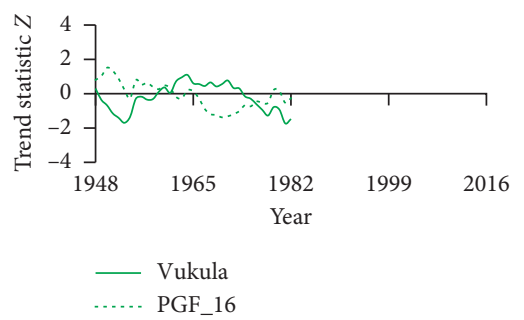

(i)

FIGURE 13: Variability of JJAS PGF and observed rainfall at stations (a) 1, (b) 2, (c) 3, (d) 4, (e) 5, (f) 6, (g) 7, (h) 8, and (i) 9.

the OND season, $H o$ was not rejected $(Z<1.96, p>0.05)$ at all stations and corresponding nearby PGF series. For the JJAS season, Ho was rejected $(Z>1.96, p<0.05)$ at only station 5 with a significant trend. Whereas most of the MAM PGF series exhibited significant trends $(Z>1.96, p<0.05)$, their corresponding observed rainfall at stations $1,2,4,5,8$, 


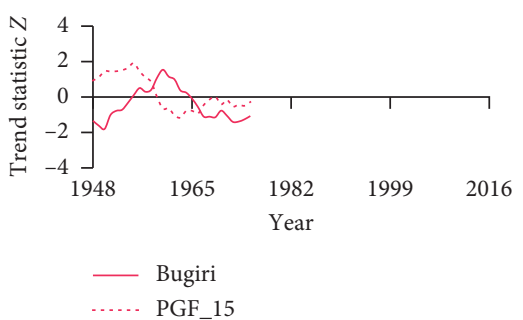

(a)

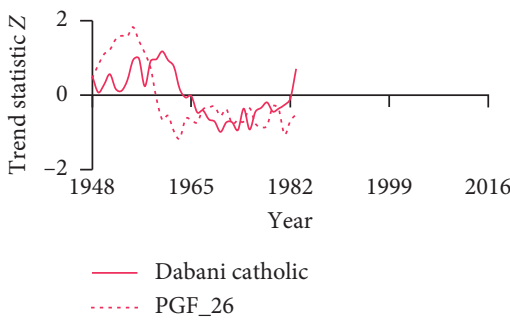

(d)

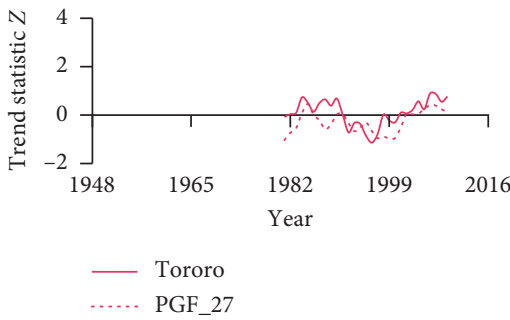

(g)

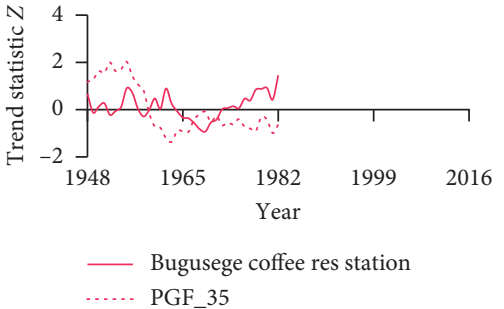

(b)

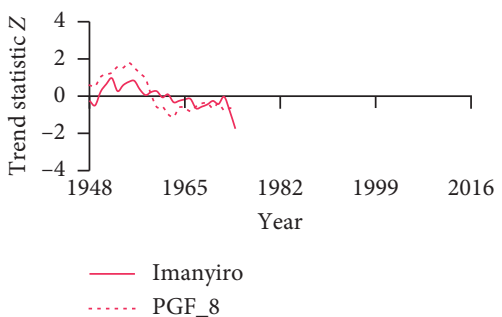

(e)

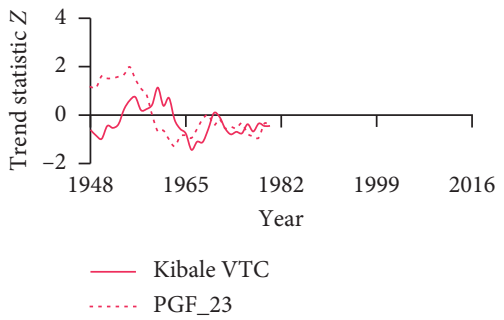

(h)

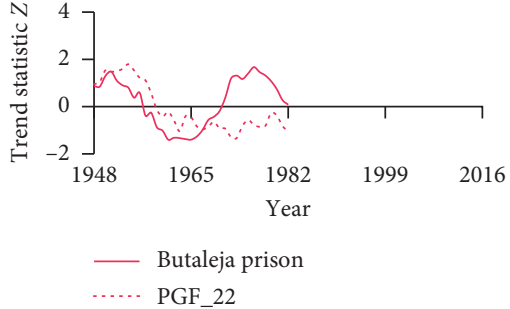

(c)

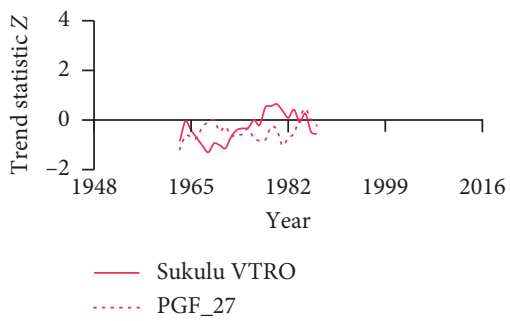

(f)

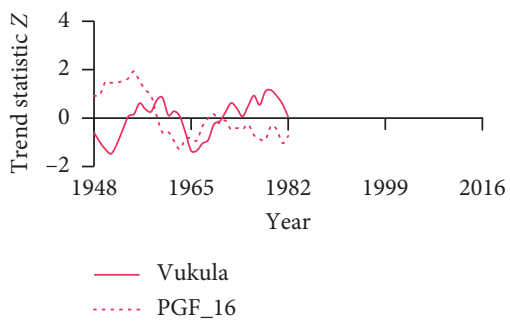

(i)

Figure 14: Variability of MAM PGF and observed rainfall at stations (a) 1, (b) 2, (c) 3, (d) 4, (e) 5, (f) 6, (g) 7, (h) 8, and (i) 9.

and 9 had insignificant trends. Furthermore, station 3 and the nearby PGF series had a significant trend $(Z>1.96$, $p<0.05)$ with the same values of $Z$ and $p$ during the MAM season. Stations 6 and 7 with their corresponding PGF series had insignificant trends during the MAM season.

\section{Conclusion}

Previous studies focused on rainfall and temperature trend and variability analyses mainly at the regional and countrywide scales. In other words, studies conducted on the analysis of trends and variability of rainfall and evapotranspiration across the Mpologoma catchment are lacking. This could be due to the lack of observed long-term data. This study evaluated the spatial and temporal changes in rainfall and evapotranspiration over Mpologoma catchment using gridded $\left(0.25^{\circ} \times 0.25^{\circ}\right)$ PGF data covering the period of 1948 to 2016. Trend and variability analyses were accomplished using a nonparametric CSD method which considers the difference between the exceedance and nonexceedance counts of data points.

Annual and MAM rainfall displayed a positive trend $(p<0.05)$, whereas OND and JJAS rainfall exhibited negative trends with $p>0.05$ and $p<0.05$, respectively. Positive subtrends in rainfall occurred in the 1950s and from the mid-2000s till the end of the study period (2016); however, negative subtrends occurred from 1960 till around 2005. The study established an integrated understanding of the rainfall in the area with an indication of wetter (drier) areas and, hence, floods (droughts). These weather events destroy properties and cause loss of lives, which necessitate wellthought adaptation strategies developed based on an integrated understanding of extreme weather events and social perception. Seasonal evapotranspiration exhibited a positive subtrend $(p>0.05)$. For the entire study period (1948-2016), there was no negative subtrend in the OND and MAM evapotranspiration. An increase in evapotranspiration has potential impacts on the soil water balance and harvest in the agricultural sector.

A comparison of the PGF and observed rainfall was made at both seasonal and annual time series by testing the null hypothesis $H_{o}$ (no correlation between observed and PGF rainfall). Although, at some locations, the $H_{o}$ was not rejected $(p<0.05)$, the PGF data overestimated and underestimated the oscillation highs and lows from observed rainfall in different areas. Thus, it is vital to continue improving the quality of PGF and other reanalyses data in reproducing observed climatology across the various regions especially in data-scarce areas. There were a number of limitations to this study. Only the uncalibrated Hargreaves method was used in estimating PET over the study area. It is possible that the uncalibrated Hargreaves method might yield biased results and thereby influence the results of analyses of trend and variability as considered in this study. 
To even out the influence due to the selection of a particular method, it is recommended that a future study on the variability and trends in PET and rainfall adopt many other approaches. Besides, the uncertainty in the choice of data resolution in the analyses of trends and variability in the hydroclimatic data should be quantified in future research. Variations in rainfall and evapotranspiration can be influenced by atmospheric anomalies [30] as well as the influence of regional and local factors [41] and these were not considered in this study. Particularly, the large-scale atmospheric conditions may result in a delayed influence on climate variability [97]. Understanding the climate variability drivers can aid in predictive planning for upcoming wet or dry conditions [27]. This could be investigated in future research.

Despite the highlighted limitations (which may be addressed in the recommended future research studies), this study provides relevant information on the rainfall and evapotranspiration trends and variation in subtrends. This is vital for careful planning of predictive adaptation to the impacts of climate variability on environmental applications which depend on water balance in the Mpologoma catchment.

\section{Data Availability}

Data used in this research can be obtained from the corresponding author upon request.

\section{Conflicts of Interest}

The authors declare no conflicts of interest.

\section{Acknowledgments}

The authors would like to acknowledge the use of Princeton Global Forcing- (PGF-) gridded data obtained online from http://hydrology.princeton.edu/data/pgf/0.5deg/ (accessed: 10 January 2020). Trends and variability were computed using the CSD-VAT (CSD-based Variability Analyses Tool) downloaded via the link https://sites.google.com/site/ conyutha/tools-to-download(accessed: 14 January 2020). The observed rainfall was obtained from the Uganda National Meteorological Authority under the Ministry of Water and Environment. The research was financially supported through the Ph.D. scholarship awarded to the first author by the Africa Center of Excellence for Water Management, Addis Ababa University, Ethiopia.

\section{References}

[1] N. Dahal, U. Shrestha, A. Tuitui, and H. Ojha, "Temporal changes in precipitation and temperature and their implications on the streamflow of rosi river, Central Nepal," Climate, vol. 7, no. 1-3, pp. 1-15, 2019.

[2] D. Guo, S. Westra, and H. R. Maier, "Sensitivity of potential evapotranspiration to changes in climate variables for different Australian climatic zones," Hydrology and Earth System Sciences, vol. 21, no. 4, pp. 2107-2126, 2017.
[3] E. Obada, E. Alamou, A. Chabi, J. Zandagba, and A. Afouda, "Trends and changes in recent and future Penman-Monteith potential evapotranspiration in Benin (West Africa)," $\mathrm{Hy}$ drology, vol. 4, no. 3-38, pp. 1-18, 2017.

[4] P. Ssentongo, A. J. B. Muwanguzi, U. Eden et al., "Changes in Ugandan climate rainfall at the village and forest level," Scientific Reports, vol. 8, no. 3551, pp. 1-19, 2018.

[5] E. Van Waeyenberge and H. Bargawi, Macroeconomic policy, Inclusive Growth and Productive Employment in Uganda, International Labour Office, Geneva, Switzerland, Employment Working Paper No. 244, 2018.

[6] Ministry of Water and Environment, Uganda Second National Communication to the United Nations Framework Convention on Climate Change, Ministry of Water and Environment, Kampala, Uganda, 2014.

[7] R. Bhatt and A. Hossain, "Concept and consequence of evapotranspiration for sustainable crop production in the era of climate change," in Advanced Evapotranspiration Methods and Applications Increasing, D. Bucur, Ed., pp. 1-14, IntechOpen, Kapurthala, India, 2019.

[8] P. Meza-Pale and A. Yúnez-Naude, "The effect of rainfall variation on agricultural households : evidence from Mexico," in Proceedings of the International Conference on Agricultural Economists, p. 24, Milan, Italy, August 2015.

[9] R. W. Mayega, "Qualitative assessment of resilience to the effects of climate variability in the three communities in Uganda," in RAN Secretariat and East African Resilience Innovation Lab (EA RILab), Makerere University, Kampala, Uganda, 2015.

[10] Ministry of Water and Environment, Mpologoma Catchment Management Plan, Ministry of Water and Environment, Kampala, Uganda, 2018.

[11] Floodlist, Uganda-deadly floods and landslides in eastern region (updated), 2020, http://floodlist.com/africa/ugandafloods-bududa-sironko-december-2019.

[12] ACAPS, Uganda: flooding and landslides in Bududa, 2020, https://www.acaps.org/sites/acaps/files/products/files/20181018_ acaps_start_briefing_note_uganda_flooding_and_landslides_ in_bududa.pdf.

[13] L. M. Atuyambe, M. Ediau, C. G. Orach, M. Musenero, and W. Bazeyo, "Land slide disaster in eastern Uganda: rapid assessment of water, sanitation and hygiene situation in Bulucheke camp, Bududa district," Environmental Health, vol. 10, no. 38, pp. 1-22, 2011.

[14] OCHA Uganda, Eastern Uganda landslides and floods situation Report 3, 2020, https://reliefweb.int/sites/reliefweb.int/ files/resources/81D1CDAB49713514C12576EA003098A5Full_Report.pdf.

[15] A. Markandya, N. Dale, J. Garcia, C. Langoya, and C. Monkhouse, "Economic assessment of the impacts of climate change in Uganda: arabica coffee production in the mount elgon region (Bududa district)," Ministry of Water and Environment, vol. 1, 2015, https://cdkn.org/wp-content/uploads/ 2015/11/Uganda_CC-Economics_Mount-Elgon_case-study. pdf.

[16] M. K. Kansiime, S. K. Wambugu, and C. A. Shisanya, "Perceived and actual rainfall trends and variability in eastern Uganda: implications for community preparedness and response," Journal of Natural Sciences Research, vol. 3, no. 8, pp. 179-195, 2013.

[17] M. Kizza, A. Rodhe, C.-Y. Xu, H. K. Ntale, and S. Halldin, "Temporal rainfall variability in the Lake Victoria Basin in east Africa during the twentieth century," Theoretical and Applied Climatology, vol. 98, no. 1-2, pp. 119-135, 2009. 
[18] P. Nyeko-Ogiramoi, P. Willems, and G. Ngirane-Katashaya, "Trend and variability in observed hydrometeorological extremes in the Lake Victoria basin," Journal of Hydrology, vol. 489 , pp. 56-73, 2013.

[19] C. Onyutha and P. Willems, "Spatial and temporal variability of rainfall in the Nile Basin," Hydrology and Earth System Sciences, vol. 19, no. 5, pp. 2227-2246, 2015.

[20] H. Alemu, A. Kaptué, G. Senay, M. Wimberly, and G. Henebry, "Evapotranspiration in the Nile basin: identifying dynamics and drivers, 2002-2011," Water, vol. 7, no. 9, pp. 4914-4931, 2015.

[21] C. Onyutha, "Statistical analyses of potential evapotranspiration changes over the period 1930-2012 in the Nile River riparian countries," Agricultural and Forest Meteorology, vol. 226-227, pp. 80-95, 2016.

[22] I. Mugume, M. Mesquita, C. Basalirwa et al., "Patterns of dekadal rainfall variation over a selected region in Lake Victoria basin, Uganda," Atmosphere, vol. 7, no. 11-150, pp. 1-23, 2016.

[23] J. Phillips and B. Mcintyre, "ENSO and interannual rainfall variability in Uganda: implications for agricultural management," International Journal of Climatology, vol. 20, no. 2, pp. 171-182, 2000.

[24] F. W. Nsubuga, J. M. Olwoch, and H. Rautenbach, "Variability properties of daily and monthly observed near-surface temperatures in Uganda: 1960-2008," International Journal of Climatology, vol. 34, no. 2, pp. 303-314, 2014.

[25] F. M. Mwaura and G. Okoboi, "Climate variability and crop production in Uganda," Journal of Sustainable Development, vol. 7, no. 2, pp. 159-172, 2014.

[26] J. G. Majaliwa, "Characterization of historical seasonal and annual rainfall and temperature trends in selected climatological homogenous rainfall zones of Uganda," Global Journal of Science Frontier Research, vol. 15, no. 4, pp. 1-21, 2015.

[27] C. Onyutha, "Geospatial trends and decadal anomalies in extreme rainfall over Uganda, east Africa," Advances in Meteorology, vol. 2016, Article ID 6935912, 15 pages, 2016.

[28] M. R. Jury, "Uganda rainfall variability and prediction," Theoretical and Applied Climatology, vol. 132, no. 3-4, pp. 905-919, 2018.

[29] A. Van Griensven, P. Ndomba, S. Yalew, and F. Kilonzo, "Critical review of SWAT applications in the upper Nile basin countries," Hydrology and Earth System Sciences, vol. 16, no. 9, pp. 3371-3381, 2012.

[30] C. Onyutha and P. Willems, "Space-time variability of extreme rainfall in the River Nile basin," International Journal of Climatology, vol. 37, no. 14, pp. 4915-4924, 2017.

[31] R. B. Blackman and J. W. Tukey, The Measurement of Power Spectra, Dover Publications, New York, NY, USA, 1959.

[32] V. Ntegeka and P. Willems, "Trends and multidecadal oscillations in rainfall extremes, based on a more than 100-year time series of 10 min rainfall intensities at Uccle, Belgium," Water Resources Research, vol. 44, no. 7, pp. 1-15, 2008.

[33] N. E. Lorenz, Empirical Orthogonal Functions and Statistical Weather Prediction. Scientific Report No. 1. Statistical Forecasting Project, Department of Meteorology, Massachusetts Institute of Technology, Cambridge, MA, USA, 1956.

[34] C. T. Haan, Statistical Methods in Hydrology, Iowa State University Press, Ames, IA, USA, 1977.

[35] P. K. Sen, "Estimates of the regression coefficient based on Kendall's tau," Journal of the American Statistical Association, vol. 63, no. 324, pp. 1379-1389, 1968.

[36] H. B. Mann, "Nonparametric tests against trend," Econometrica, vol. 13, no. 3, pp. 245-259, 1945.
[37] M. G. Kendall, Rank Correlation Methods, Charles Griffin, London, UK, 4th edition, 1975.

[38] E. L. Lehmann, Nonparametrics: Statistical Methods Based on Ranks, Holden Day, San-Francisco, CA, USA, 1975.

[39] C. Spearman, "The proof and measurement of association between two things," The American Journal of Psychology, vol. 15, no. 1, pp. 72-101, 1904.

[40] C. Onyutha, "Identification of sub-trends from hydro-meteorological series," Stochastic Environmental Research and Risk Assessment, vol. 30, no. 1, pp. 189-205, 2016.

[41] C. Onyutha, G. Acayo, and J. Nyende, "Analyses of precipitation and evapotranspiration changes across the Lake Kyoga Basin in east Africa," Water, vol. 12, no. 4:1134, pp. 1-23, 2020.

[42] T. M. Cengiz, H. Tabari, C. Onyutha, and O. Kisi, "Combined use of graphical and statistical approaches for analyzing historical precipitation changes in the black sea region of Turkey," Water, vol. 12, no. 3:705, pp. 1-19, 2020.

[43] J. Vido, P. Nalevanková, J. Valach, Z. Šllach, and T. Tadesse, "Drought analyses of the horné požitavie region (Slovakia) in the period 1966-2013," Advances in Meteorology, vol. 2019, Article ID 3576285, 10 pages, 2019.

[44] L. Tang and Y. Zhang, "Considering abrupt change in rainfall for flood season division: a case study of the Zhangjia Zhuang reservoir, based on a new model," Water, vol. 10, no. 9:1152, pp. 1-16, 2018.

[45] A. Pirnia, M. Golshan, H. Darabi, J. Adamowski, and S. Rozbeh, "Using the Mann-Kendall test and double mass curve method to explore stream flow changes in response to climate and human activities," Journal of Water and Climate Change, vol. 10, no. 4, pp. 725-742, 2018.

[46] C. Onyutha, "Trends and variability in African long-term precipitation," Stochastic Environmental Research and Risk Assessment, vol. 32, no. 9, pp. 2721-2739, 2018.

[47] P. Camberlin, "Nile basin climates," in the Nile: Origin, Environments, Limnology and Human Use, H. J. Dumont, Ed., pp. 307-333, Springer, Berlin, Germany, 2009.

[48] M. Kigobe and A. Van Griensven, "Assessing hydrological response to change in climate: statistical downscaling and hydrological modelling within the upper Nile," in Proceedings of the 2010 International Congress on Environmental Modelling and Software Modelling for Environment's Sake, pp. 110, Ottawa, Canada, July 2010.

[49] H. Wackernagel, "Ordinary kriging," in Multivariate Geostatistics, pp. 74-81, Springer, Berlin, Heidelberg, 1995.

[50] I. K. Mesić, "Comparison of ordinary and universal Kriging interpolation techniques on a depth variable (a case of linear spatial trend), case study of the Šandrovac field," The MiningGeology-Petroleum Engineering Bulletin, vol. 31, no. 2, pp. 41-58, 2016.

[51] I. Harris, P. D. Jones, T. J. Osborn, and D. H. Lister, “Updated high-resolution grids of monthly climatic observations-the CRU TS3.10 Dataset," International Journal of Climatology, vol. 34, no. 3, pp. 623-642, 2014.

[52] H. Ashouri, K.-L. Hsu, S. Sorooshian et al., "PERSIANNCDR: daily precipitation climate data record from multisatellite observations for hydrological and climate studies," Bulletin of the American Meteorological Society, vol. 96, no. 1, pp. 69-83, 2015.

[53] G. J. Huffman, D. T. Bolvin, E. J. Nelkin et al., "The TRMM Multisatellite Precipitation Analysis (TMPA): quasi-global, multiyear, combined-sensor precipitation estimates at fine scales," Journal of Hydrometeorology, vol. 8, no. 1, pp. 38-55, 2007. 
[54] N. S. Novella and W. M. Thiaw, "African rainfall climatology version 2 for famine early warning systems," Journal of Applied Meteorology and Climatology, vol. 52, no. 3, pp. 588-606, 2013.

[55] J. Sheffield, G. Goteti, and E. F. Wood, "Development of a 50year high-resolution global dataset of meteorological forcings for land surface modeling," Journal of Climate, vol. 19, no. 13, pp. 3088-3111, 2006.

[56] I. Harris, T. J. Osborn, P. Jones, and D. Lister, "Version 4 of the CRU TS monthly high-resolution gridded multivariate climate dataset," Scientific Data, vol. 7, no. 1, pp. 1-18, 2020.

[57] N. Khan, S. Shahid, T. Ismail, K. Ahmed, and N. Nawaz, "Trends in heat wave related indices in Pakistan," Stochastic Environmental Research and Risk Assessment, vol. 33, no. 1, pp. 287-302, 2018.

[58] M. S. Nashwan and S. Shahid, "Spatial distribution of unidirectional trends in climate and weather extremes in Nile river basin," Theoretical and Applied Climatology, vol. 137, no. 1-2, pp. 1181-1199, 2019.

[59] M. S. Nashwan, S. Shahid, and N. Abd Rahim, "Unidirectional trends in annual and seasonal climate and extremes in Egypt," Theoretical and Applied Climatology, vol. 136, no. 1-2, pp. 457-473, 2018.

[60] C. Onyutha and P. Willems, "Influence of spatial and temporal scales on statistical analyses of rainfall variability in the River Nile basin," Dynamics of Atmospheres and Oceans, vol. 77, pp. 26-42, 2017.

[61] E. Kalnay, M. Kanamitsu, R. Kistler et al., "The NCEP/NCAR 40-year reanalysis Project," Bulletin of the American Meteorological Society, vol. 77, no. 3, pp. 437-471, 1996.

[62] U. Ehret, E. Zehe, V. Wulfmeyer, K. Warrach-Sagi, and J. Liebert, "HESS Opinions "Should we apply bias correction to global and regional climate model data?"” Hydrology and Earth System Sciences, vol. 16, no. 9, pp. 3391-3404, 2012.

[63] S. Nair, G. Srinivasan, and R. Nemani, "Evaluation of multisatellite TRMM derived rainfall estimates over a western state of India," Journal of the Meteorological Society of Japan, vol. 87, no. 6, pp. 927-939, 2009.

[64] E. Sharifi, B. Saghafian, and R. Steinacker, "Bias correction of satellite precipitation products based on concept of copula," Geophysical Research Abstracts, vol. 20, 2018.

[65] JICA, The Development Study on Water Resources Development and Management for Lake Kyoga Basin in the Republic of Uganda, Water Resources Management, Kampala, Uganda, 2011.

[66] D. Shepard, "A two-dimensional interpolation function for irregularly- spaced data," in Proceedings of the 23rd National Conference, pp. 517-524, Las Vegas, NV, USA, August 1968.

[67] T. Chen, L. Ren, F. Yuan et al., "Comparison of spatial interpolation schemes for rainfall data and application in hydrological modeling," Water, vol. 9, no. 5:342, pp. 1-18, 2017.

[68] S. Das, "Extreme rainfall estimation at ungauged sites: comparison between region-of-influence approach of regional analysis and spatial interpolation technique," International Journal of Climatology, vol. 39, no. 1, pp. 407-423, 2019.

[69] K. C. Lam, R. G. Bryant, and J. Wainright, "Application of spatial interpolation method for estimating the spatial variability of rainfall in Semiarid New Mexico, USA," Mediterranean Journal of Social Sciences, vol. 6, no. 4, pp. 108-116, 2015.

[70] C. Onyutha, Variability of Rainfall and River Flow in the Nile Basin Variability of Rainfall and River Flow in the Nile Basin, $\mathrm{Ph}$. D. thesis, Department of Civil Engineering, Ku Leuven, Leuven, Belgium, 2017.
[71] G. Pellicone, T. Caloiero, G. Modica, and I. Guagliardi, "Application of several spatial interpolation techniques to monthly rainfall data in the Calabria region (southern Italy)," International Journal of Climatology, vol. 38, no. 9, pp. 3651-3666, 2018.

[72] G. Y. Lu and D. W. Wong, "An adaptive inverse-distance weighting spatial interpolation technique," Computers \& Geosciences, vol. 34, no. 9, pp. 1044-1055, 2008.

[73] P. Goovaerts, "Geostatistical approaches for incorporating elevation into the spatial interpolation of rainfall," Journal of Hydrology, vol. 228, no. 1-2, pp. 113-129, 2000.

[74] C. D. Lloyd, "Assessing the effect of integrating elevation data into the estimation of monthly precipitation in Great Britain," Journal of Hydrology, vol. 308, no. 1-4, pp. 128-150, 2005.

[75] R. G. Allen, L. S. Pereira, D. Raes, and M. Smith, Crop Evapotranspiration - Guidelines for Computing Crop Water Requirements-FAO Irrigation and Drainage Paper 56, FAO-Food and Agriculture Organization of the United Nations, Rome, Italy, 1998.

[76] G. H. Hargreaves and Z. A. Samni, "Estimation of potential evapotranspiration," Journal of Irrigation and Drainage Division, vol. 108, no. 3, pp. 225-230, 1982.

[77] G. H. Hargreaves and Z. A. Samni, "Reference crop evapotranspiration from temperature," Transactions - American Society of Agricultural Engineers, vol. 1, pp. 96-99, 1985.

[78] C. W. Thornthwaite, "An approach toward a rational classification of climate," Geographical Review, vol. 38, no. 1, pp. 55-94, 1948.

[79] W. R. Hamon, Computation of Direct Runoff Amounts from Storm Rainfall, pp. 52-62, International Association of Sciences Hydrological Publications, Wallingford, UK, 1963.

[80] E. T. Linacre, "A simple formula for estimating evaporation rates in various climates, using temperature data alone," Agricultural Meteorology, vol. 18, no. 6, pp. 409-424, 1977.

[81] H. F. Blaney and W. D. Criddle, Determining Water Requirements in Irrigated Areas from Climatological and Irrigation Data, U.S. Soil Conservation Service, Washington, DC, USA, 48th edition, 1950.

[82] W. Abtew, "Evapotranspiration measurements and modeling for three wetland systems in south Florida," Journal of the American Water Resources Association, vol. 32, no. 3, pp. 465-473, 1996.

[83] C. H. B. Priestley and R. J. Taylor, "On the assessment of surface heat flux and evaporation using large-scale parameters," Monthly Weather Review, vol. 100, no. 2, pp. 81-92, 1972.

[84] G. F. Makkink, "Testing the Penman formula by means of lysimeters," Journal Institute of Water Engineers, vol. 11, no. 3, pp. 277-288, 1957.

[85] C. Rohwer, "Evaporation from free water surfaces," USDA Technical Bulletin, vol. 271, pp. 1-96, 1931.

[86] Z. Li, Y. Yang, G. Kan, and Y. Hong, "Study on the applicability of the Hargreaves potential evapotranspiration estimation method in CREST distributed hydrological model (version 3.0) applications," Water, vol. 10, no. 12:1882, pp. 1-15, 2018.

[87] C. Seong, V. Sridhar, and M. M. Billah, "Implications of potential evapotranspiration methods for streamflow estimations under changing climatic conditions," International Journal of Climatology, vol. 38, no. 2, pp. 896-914, 2018.

[88] H. Tabari and P. H. Talaee, "Local calibration of the Hargreaves and Priestley-Taylor equations for estimating reference evapotranspiration in arid and cold climates of Iran 
based on the Penman-Monteith model," Journal of Hydrologic Engineering, vol. 16, no. 10, pp. 837-845, 2011.

[89] G. H. Hargreaves and R. G. Allen, "History and evaluation of hargreaves evapotranspiration equation," Journal of Irrigation and Drainage Engineering, vol. 129, no. 1, pp. 53-63, 2003.

[90] H. Theil, "A rank-invariant method of linear and polynomial regression analysis," in Nederlandse Akademie Van Wetenschappen, Series A, vol. 53, pp. 386-392, Statistical Department of the Mathematisch Centrum, Amsterdam, Netherlands, 1950.

[91] C. Onyutha, "On rigorous drought assessment using daily time scale: non-stationary frequency analyses, revisited concepts, and a new method to yield non-parametric indices," Hydrology, vol. 4, no. 4:48, pp. 1-43, 2017.

[92] F. W. N. Nsubuga, O. J. Botai, J. M. Olwoch, C. J. d. Rautenbach, Y. Bevis, and A. O. Adetunji, "The nature of rainfall in the main drainage sub-basins of Uganda," Hydrological Sciences Journal, vol. 59, no. 2, pp. 278-299, 2014.

[93] V. Thomas and R. López, "Global increase in climate-related disasters," SSRN Electronic Journal, vol. 466, 2015.

[94] J. D. Salas and J. Obeysekera, "Revisiting the concepts of return period and risk for nonstationary hydrologic extreme events," Journal of Hydrologic Engineering, vol. 19, no. 3, pp. 554-568, 2014.

[95] J. O. Adejuwon, "Food crop production in Nigeria. II. Potential effects of climate change," Climate Research, vol. 32, pp. 229-245, 2006

[96] V. Ongoma, H. Chen, and G. W. Omony, "Variability of extreme weather events over the equatorial East Africa, a case study of rainfall in Kenya and Uganda," Theoretical and Applied Climatology, vol. 131, no. 1-2, pp. 295-308, 2016.

[97] H. Tabari and P. Willems, "Lagged influence of Atlantic and Pacific climate patterns on European extreme precipitation," Scientific Reports, vol. 8, no. 1, pp. 1-10, 2018. 